\title{
A taxonomic and morphological redescription of Potamotrygon falkneri Castex \& Maciel, 1963 (Chondrichthyes: Myliobatiformes: Potamotrygonidae)
}

\author{
João Paulo C. B. da Silva and Marcelo R. de Carvalho
}

A taxonomic revision of two nominal species of freshwater stingrays of the genus Potamotrygon previously considered valid, Potamotrygon falkneri Castex \& Maciel, 1963 and Potamotrygon castexi Castello \& Yagolkowski, 1969, was conducted based on a detailed analysis of external and internal morphology, including a morphometric and meristic study of specimens from the recorded range of both species. The taxonomic status of the nominal species P. menchacai Achenbach, 1967, treated by previous authors as a junior synonym of $P$. falkneri, was also evaluated. These nominal species, which constitute what has been called the falkneri-castexi complex, were found to represent examples of chromatic variation present in a single species, given that intermediate patterns of coloration are common and the remaining characters analyzed are not consistent enough for separation at the specific level. Consequently, Potamotrygon falkneri is considered valid, whereas the nominal species Potamotrygon castexi and Potamotrygon menchacai are concluded to be junior synonyms of $P$. falkneri. Additionally, a putative new species is identified from the río Madre de Díos in Peru, which has some characters that do not correspond to $P$. falkneri. This species, known from few individuals, is here provisionally treated as Potamotrygon sp.

Uma revisão taxonômica de duas espécies nominais de raias de água doce do gênero Potamotrygon previamente consideradas válidas, Potamotrygon falkneri Castex \& Maciel, 1963 e Potamotrygon castexi Castello \& Yagolkowski, 1969, foi realizada baseada numa análise detalhada abrangendo aspectos da morfologia externa e interna, incluindo um estudo morfométrico e merístico de espécimes provenientes da distribuição registrada dessas espécies. Além dessas espécies, o status taxonômico da espécie nominal Potamotrygon menchacai Achenbach, 1967, tratada por autores prévios como sinônimo júnior de Potamotrygon falkneri, foi avaliado. As espécies nominais que constituem o que foi chamado de complexo falkneri-castexi representam exemplos da variação cromática encontrados em uma única espécie, uma vez que ocorrem padrões intermediários de coloração e os caracteres restantes não são consistentes para separação em nível específico. Sendo assim, a espécie nominal $P$. falkneri é considerada válida e as espécies nominais $P$. castexi e $P$. menchacai sinônimos juniores desta. Adicionalmente, uma possível espécie nova é apresentada do río Madre de Dios no Peru, sendo esta portadora de alguns caracteres destoantes de $P$. falkneri. Essa espécie, conhecida de poucos indivíduos, é tratada aqui provisoriamente como Potamotrygon sp.

Key words: Neotropical freshwater stingrays, Potamotrygon castexi, Skeletal anatomy, South America.

\section{Introduction}

Four genera are recognized in the South American freshwater stingray family Potamotrygonidae: Paratrygon Duméril, 1865, Potamotrygon Garman, 1877, Plesiotrygon Rosa, Castello \& Thorson, 1987 and Heliotrygon Carvalho \& Lovejoy, 2011 (Rosa et al., 1987; Carvalho et al., 2003; Carvalho $\&$ Lovejoy, 2011). The genera Paratrygon and Plesiotrygon are presently monospecific, whereas Heliotrygon has two valid species (Carvalho \& Lovejoy, 2011) and Potamotrygon has approximately 20 valid species (Carvalho et al., 2003; Rosa et al., 2008). Identification at generic level is straightforward, however many species of Potamotrygon are precariously delimited. This is due, in part, to elevated variation in coloration found in conspecific individuals of certain species, and to the existence of similar coloration patterns in individuals of presumably separate species (Carvalho et al., 2003). Given this scenario, it is fair to state that species identification based

Departamento de Zoologia, Instituto de Biociências, Universidade de São Paulo. Rua do Matão, Travessa 14, 101, 05508-900 São Paulo, SP, Brazil.jpcbs@ib.usp.br, mrcarvalho@ib.usp.br 
on coloration is frequently problematical. Identification is further complicated because many meristic (number of vertebrae, tooth rows, etc.) and morphometric characters present little consistent variation between species, diminishing the relevance of features that are traditionally diagnostic in batoids.

In the present study, two species of Potamotrygon that are currently considered valid were taxonomically revised: Potamotrygon falkneri Castex \& Maciel, 1963 and Potamotrygon castexi Castello \& Yagolkowski, 1969. Besides these two species, the taxonomic status of a third nominal species, Potamotrygon menchacai Achenbach, 1967, usually treated as a junior synonym of Potamotrygon falkneri (e.g., Rosa, 1985; Carvalho et al., 2003), was also evaluated. Our initial suspicion, after the examination of a significant amount of material, was that these three nominal species may, in fact, represent the extremes of chromatic variation found within a single species.

Potamotrygon falkneri, originally described from río Paraná (near Santa Fé, Argentina), is restricted to the Paraná-Paraguay basin, occurring from the Pantanal region (rios Cuiabá, Piquiri, among others) to the lower río Paraná. This species presents a disc that is generally slightly longer than wide, with a mid-dorsal region covered by dermal denticles but with smooth disc margins, and spines on dorsal caudal region disposed in irregular parallel rows. The dorsal disc surface has a dark brown background coloration, with small reniform, round or oval, orange to yellow spots. The dorsal surfaces of tail and pelvic fins also present the same color pattern found on the dorsal disc.

Potamotrygon castexi, which was originally described from Rosário, Argentina (río Paraná), is one of only two species that has been recorded in both the Amazon and ParanáParaguay basins, having been found in Bolivia (Madre de Díos, Guaporé, and Beni Rivers), Peru (río Marañon) and in the rio Solimões, in addition to several localities from the rio Paraguay (Rosa, 1985). This species presents, according to Rosa (1985), the disc slightly longer than wide, with small yellowish spots that fuse forming vermicular patterns or rosettes on the back of the disc, tail and pelvic fins, with a light to dark brown background coloration. There are also more developed dermal denticles on the mid region of the disc, and tail spines with circular bases that occur in irregular rows.

Potamotrygon menchacai was originally described from río Colastiné (a tributary of rio Paraná), Santa Fé, Argentina. According to its original description, this species presents a disc slightly longer than wide, with a smooth dorsal surface except at its mid region where dermal denticles are arranged irregularly from the interorbital area to the tip of the tail. The tail presents irregular rows of backward-pointing spines. In addition, the dorsal surface of disc, pelvic fins and tail are yellow to orange in coloration, intersected by a black, labyrinthic reticulation which circumscribes broad vermicular formations.
Considering that many intermediate patterns of coloration exist between these nominal species, and that they were described from specimens collected only about $100 \mathrm{~km}$ apart (i.e., their type localities are very proximal), there was a strong possibility that they represented a single, albeit polychromatic, species. A taxonomic and morphological revision of these species was therefore undertaken with the intention to correctly identify and apply the nominal species Potamotrygon falkneri, P. castexi, and P. menchacai. In the course of this study, a probable new species was discovered showing characteristics distinct from the species reviewed here.

\section{Material and Methods}

Measurements of potamotrygonid specimens were modified from Bigelow \& Schroeder (1953) and Rosa (1985) and were transformed into percentages of disc width (\% DW) to allow direct comparisons. Measurements taken on specimens are as follows: total length, distance from tip of snout to tip of tail; disc length, greatest distance from tip of snout to posterior margin of disc; disc width, greatest distance between lateral margins of disc; interorbital space, distance between upper margins of eyes; interspiracular space, distance between posterior margins of spiracles; eye length, greatest horizontal diameter of exposed portion of eyeball; spiracle length, oblique distance between anterior and posterior spiracular margins; sting length, length of exposed portion of caudal sting; sting width, width taken at the origin of caudal sting; preorbital length, distance from tip of snout to anterior margin of eyes; prenasal length, distance from tip of snout to anterior margin of nostrils; preoral length, distance from tip of snout to median portion of mouth slit; internarial space, distance between anterior margins of nostrils; mouth width, greatest distance between lateral edges of mouth; space between $1^{\text {st }}$ branchial slits, distance between inner margins of first pair of gill slits; space between $5^{\text {th }}$ branchial slits, distance between inner margins of fifth pair of gill slits; branchial basket length, distance between inner margins of first and fifth gill slits; pelvic fin length, length of anterior margin of pelvic fin; pelvic fin width, greatest width between posterior margins of pelvic fins; clasper external edge, distance from posterior margin of pelvic fin to tip of clasper; clasper internal edge, distance from posterior margin of cloaca to tip of clasper; cloaca to tail tip, distance from posterior margin of cloaca to tip of tail; tail width, greatest width of base of tail; snout to cloaca, distance from tip of snout to proximal margin of cloaca; pectoral axil to posterior edge of pelvic fin, distance from pectoral axil, at the joint of posterior margin of disc and tail, to posterior margin of pelvic fin; cloaca to sting, distance from posterior margin of cloaca to base of first caudal sting .

Counts are according to Compagno \& Roberts (1982) and Rosa (1985), excluding lower median teeth, mid-dorsal spines, and caudal vertebrae to base of sting, which were not recorded. Skeletal structures were studied from dissected, radiographed, and cleared and stained individuals (these 
prepared according to Dingerkus \& Uhler, 1977). Some specimens were boiled along with potassium hydroxide $(\mathrm{KOH})$ to facilitate removal of their flesh (as outlined in Compagno, 1988); anatomical structures were subsequently preserved in ethanol (70\%). Photographs were taken with a digital camera, and illustrations were done employing a stereomicroscope equipped with a camera lucida attachment. X-ray radiographs were taken on Kodak mammography film (Min-R2000). Terminology for skeletal structures follows Nishida (1990) and Carvalho et al. (2004), for dermal denticles Deynat \& Séret (1996), for internal and external clasper components Taniuchi \& Ishihara (1990), for dentition Compagno (1973), and for lateral-line canals Garman (1888), Ewart \& Mitchell (1892), and Chu \& Wen (1979).

Material examined is from the following institutions: Academy of Natural Sciences of Philadelphia, Philadelphia (ANSP); Field Museum of Natural History, Chicago (FMNH); Natural History Museum of Los Angeles County, Los Angeles (LACM); Museo Argentino de Ciencias Naturales Bernardino Rivadavia, Buenos Aires (MACN); Museo Florentino Ameghino, Santa Fé (MFA); Museu de Zoologia da Universidade de São Paulo, São Paulo (MZUSP); Núcleo de Pesquisa em Limnologia, Ictiologia e Aquicultura, Maringá (NUP); and Museum of Zoology, University of Michigan, Ann Arbor (UMMZ). Specimens were also collected during field-work in the rio Cuiabá, Mato Grosso (July, 2006). Specimens were fixed in loco through injections of $10 \%$ formalin and subsequently transferred to $70 \%$ ethanol. Abbreviations used throughout the text include DL for disc length, DW for disc width, and TL for total length.

\section{Potamotrygonidae Garman, 1913 Potamotrygon Garman, 1877 Potamotrygon falkneri Castex \& Maciel, 1963} Figs. 1-11

Potamotrygon vistrix (lapsus for histrix): Castex, 1963a:52, fig.10 (misidentification).

Potamotrygon histrix: Castex, 1963a:54, 119 (misidentification). Potamotrygon falkneri Castex \& Maciel in Castex, 1963b:5661, figs. 16-17 (original description, río Paraná, Santa Fé, Argentina); Castex, 1964:31 (revision); Castex, 1965:45 (allotype [sic] description); Castex, 1967a:487-489 (dermal denticles of Potamotrygon species); Castex, 1967b:493, 495 (teeth of Potamotrygon species); Achenbach, 1971:2, 3, 6, 7, 8 (cited); Achenbach \& Achenbach, 1976:4, 28 (cited); Rosa, 1985:175-192, figs. 45-49 (revision, redescription, figured); Taniuchi \& Ishihara, 1990:15 (anatomical comparison of claspers); Compagno \& Cook, 1995:67, 72, 73, 80 (listed); Ishihara \& Taniuchi, 1995:91, 95, 97 (listed); Gómez \& Chebez, 1996:46 (listed); Britski et al., 1999:21 (brief account, illustrated); Compagno, 1999:495 (listed); Marques, 2000:42, 55, 107, 162, 163, 166, 167, 169 (helminth parasites); Bor, 2002:30 (listed); Carvalho et al., 2003:24 (accepted as valid, taxonomic account); López et al., 2003:6 (listed); Marques et al., 2003:368, 371, 373-375 (cited); Carvalho et al., 2004:10, 61, 93 (anatomical account); Menni, 2004:70 (cited); Compagno, 2005:540 (listed); López et al., 2005:314, 324 (listed); Deynat, 2006:491 (cited); Lonardoni et al., 2006:195-200, 202 (ecological study, upper rio Paraná); Rosa \& Carvalho, 2007:17 (listed); Garrone Neto et al., 2007:206, 207 (biological study, upper rio Paraná); Graça \& Pavanelli, 2007:22, 23 (brief account, upper rio Paraná); Silva \& Uieda, 2007:221-226 (biological study, upper rio Paraná).

Potamotrygon menchacai Achenbach, 1967:1-8 (original description, río Colastiné, Santa Fé, Argentina); Castex, 1967a:485, 487, 488 (dermal denticles of Potamotrygon species); Castex, 1967b:493 (teeth of Potamotrygon species); Achenbach, 1971:2-7 (cited); Achenbach \& Achenbach, 1976:4, 28 (cited); Rosa, 1985:175-177 (cited as a synonym of $P$. falkneri); Carvalho, 2001:1168 (cited); Carvalho et al., 2003:24 (in synonymy of $P$. falkneri); Velte, 2005:53 (cited).

Potamotrygon castexi Castello \& Yagolkowski, 1969:1-21 (original description, río Paraná, Rosário, Argentina); Achenbach \& Achenbach, 1976:4, 28 (cited); Rosa, 1985:126-140, figs. 31-34 (accepted as valid; redescription); Ortega \& Vari, 1986:6 (listed); Nishida, 1990:58, 62, 90, 92, 94 (anatomical description); Compagno \& Cook, 1995:67, 72, 73, 80, 81 (listed); Deynat \& Séret, 1996:81 (dermal denticles); Compagno, 1999:495 (listed); Bor, 2002:30 (listed); Carvalho et al., 2003:24 (accepted as valid, taxonomic account); López et al., 2003:6 (listed); Menni, 2004:70 (listed); Compagno, 2005:540 (listed); Deynat, 2006:491 (cited); Rosa \& Carvalho, 2007:17 (listed). [NEW SYNONYM].

Material examined. (83 specimens). ANSP 142482 (male, 429 $\mathrm{mm}$ DW), río Manu below Boca Pinquen, Gomero, Peru, $12^{\circ} 11^{\text {'S }}$ 7058'W, 10 Aug 1977; ANSP 142483 (male, 265 mm DW), same data as ANSP 142482; ANSP 142484 (male, $374 \mathrm{~mm} \mathrm{DW),}$ tributary on SW bank of río Manu, $7 \mathrm{~km}$ below Boca Pinquen, Peru, $12^{\circ} 12^{\prime}$ 'S 7059'W, 11 Aug 1977; ANSP 142486 (male, 386 mm DW), same data as ANSP 142482; ANSP 142487 (female, $406 \mathrm{~mm}$ DW), same data as ANSP 142484; FMNH 84091 (male, $354 \mathrm{~mm}$ DW), río San Alejandro, near Puerto Nuevo, río Pachitea drainage, Peru; LACM 39934-1 (female, 286 mm DW), río Yutupis, Shiringa, Amazonas, Peru; LACM 39942-1 (male, 432 mm DW), same data as LACM 39934-1; LACM 41772-2 (male, $225 \mathrm{~mm}$ DW), río Santiago, small "quebrada" across from La Poza, Amazonas, Peru; MACN 2732 (female neonate, $110 \mathrm{~mm} \mathrm{DW}$ ), riacho Formosa, rio Paraguai affluent, Brazil; MACN 9092 (male, 578 mm DL; disc damaged), río Colastiné Sul, Província de Santa Fé, Argentina; MACN 9093 (male, 476 mm DW), same data as MACN 9092; MFA 73 (female, $351 \mathrm{~mm}$ DW), riacho Santa Fé, Província de Santa Fé, Argentina, 24 Apr 1951; MFA 235 (female, 286 mm DL; disc damaged), río Paraná, Província de Santa Fé, Argentina, Paratype of Potamotrygon falkneri Castex \& Maciel, 1963, coll. Castex \& Maciel, June 1963 (fig. 2a-c); MZUSP 106255 (female, $279 \mathrm{~mm}$ DW), rio Paraná, Paraná basin, municipal district of Jupiá, Três Lagoas, State of Mato Grosso do Sul, Brazil, 2047'24”'S 51³9'W, 15 Dec 2003; MZUSP 106256 (female, 338 
mm DW), same data as MZUSP 106255; MZUSP 106257 (female, $275 \mathrm{~mm}$ DW), same data as MZUSP 106255; MZUSP 106268 (male, $305 \mathrm{~mm}$ DW), same data as MZUSP 106255; MZUSP 106269 (female, $264 \mathrm{~mm}$ DW), same data as MZUSP 106255; MZUSP 106258 (female, $292 \mathrm{~mm} \mathrm{DW}$ ), same data as MZUSP 106255; MZUSP 106270 (female, $372 \mathrm{~mm} \mathrm{DW),} \mathrm{same} \mathrm{data} \mathrm{as}$ MZUSP 106255; MZUSP 106259 (female, $292 \mathrm{~mm} \mathrm{DW}$ ), same data as MZUSP 106255; MZUSP 106271 (male, 286 mm DW), same data as MZUSP 106255; MZUSP 106260 (female, $322 \mathrm{~mm}$ DW), same data as MZUSP 106255; MZUSP 106266 (female, $490 \mathrm{~mm}$ DW), same data as MZUSP 106255; MZUSP 106267 (female, $518 \mathrm{~mm}$ DW), same data as MZUSP 106255; MZUSP 106261 (female, $280 \mathrm{~mm}$ DW), same data as MZUSP 106255; MZUSP 106262 (male, $273 \mathrm{~mm}$ DW), same data as MZUSP 106255; MZUSP 106263 (female, $256 \mathrm{~mm} \mathrm{DW}$ ), same data as MZUSP 106255; MZUSP 106265 (male, $231 \mathrm{~mm}$ DW), same data as MZUSP 106255; MZUSP 14578 (female, 388 mm DW), rio Piquiri, Paraguai basin, Brazil, $17^{\circ} 12^{\prime}$ S $54^{\circ} 09^{\prime} \mathrm{W}$, Oct 1978; MZUSP 14848 (male, 420 mm DW), Taiamã's Reservatory, rio Paraguai, Brazil, 15²10'59'S 56²4'W, 8 Aug 1980; MZUSP 14852 (male, $371 \mathrm{~mm}$ DW), Fazenda Descalvados, rio Paraguai, Brazil, $16^{\circ} 44^{\prime} \mathrm{S} 57^{\circ} 45^{\prime} \mathrm{W}, 8$ Sep 1980; MZUSP 81089 (female, $435 \mathrm{~mm}$ DW), same data as MZUSP 106255; MZUSP 81090 (female, 355 $\mathrm{mm}$ DW), same data as MZUSP 106255; MZUSP 81091 (male, $310 \mathrm{~mm}$ DW), same data as MZUSP 106255; MZUSP 81092 (female, $385 \mathrm{~mm}$ DW), same data as MZUSP 106255; MZUSP 81093 (female, $370 \mathrm{~mm}$ DW), same data as MZUSP 106255; MZUSP 81094 (female, $352 \mathrm{~mm}$ DW), same data as MZUSP 106255; MZUSP 81095 (female, $398 \mathrm{~mm} \mathrm{DW}$ ), same data as MZUSP 106255; MZUSP 107667 (male, 362 mm DW), río Madre de Díos, municipal district of Boca Manu, upper Amazon basin, State of Madre de Díos, Peru, 1240'S 7104'06”W, May 2001; MZUSP 107668 (female, $265 \mathrm{~mm}$ DW), same data as MZUSP 107667; MZUSP 107669 (male, $293 \mathrm{~mm} \mathrm{DW),} \mathrm{same} \mathrm{data} \mathrm{as}$ MZUSP 107667; MZUSP 107670 (male, 300 mm DW), same data as MZUSP 107667; MZUSP 107671 (male, $351 \mathrm{~mm}$ DW), same data as MZUSP 107667; MZUSP 107672 (male, $291 \mathrm{~mm}$ DW), same data as MZUSP 107667; MZUSP 107673 (male, 348 mm DW), same data as MZUSP 107667; MZUSP 108680 (female, $350 \mathrm{~mm}$ DW), rio Casca, upper rio Paraguai basin, municipal district of Chapada dos Guimarães, state of Mato Grosso, Brazil, $15^{\circ} 01^{\prime}$ 'S, 55³2'W, 17 Apr 2000; MZUSP 108681 (male, 350 mm $\mathrm{DW})$, rio Manso, upper rio Paraguai basin, municipal district of Nobres, boundary with Rosário Oeste, state of Mato Grosso, Brazil, 20 Mar 2000; MZUSP 108682 (neonate, $161 \mathrm{~mm}$ DW), rio Aricá Mirim, rio Cuiabá affluent, rio Paraguai basin, state of Mato Grosso, Brazil; MZUSP 108683 (male, $365 \mathrm{~mm}$ DW), rio Cuiabá, upper rio Paraguai basin, municipal district of Nobres, boundary with Rosário Oeste, state of Mato Grosso, Brazil, 17 Jun 2000; NUP 2107 (male, 280 mm DW), rio Cuiabazinho, affluent of rio Cuiabá, state of Mato Grosso, Brazil; NUP 2917 (female, $325 \mathrm{~mm}$ DW), same data as MZUSP 108681; NUP 2922 (female, $501 \mathrm{~mm}$ DW), same data as MZUSP 108682; NUP 2923 (male, $380 \mathrm{~mm}$ DW), same data as NUP 2107; NUP 2945 (female, $403 \mathrm{~mm}$ DW), same data as MZUSP 108683; NUP 2968 (male, $235 \mathrm{~mm}$ DW), affluent of rio Cuiabá, bahia Sinhá Mariana, rio Paraguai basin, state of Mato Grosso, Brazil; NUP 3016 (male, $257 \mathrm{~mm}$ DW), rio Casca, upper rio Paraguai basin, municipal district of Chapada dos Guimarães, state of Mato Grosso, Brazil, $15^{\circ} 01^{\prime} \mathrm{S}, 55^{\circ} 32^{\prime} \mathrm{W}, 17 \mathrm{Aug}$ 2003; NUP 3220 (female, $230 \mathrm{~mm}$ DW), rio Manso, rio Cuiabá affluent, rio Paraguai basin, state of Mato Grosso, Brazil; MZUSP 108684 (female, 325 mm DW), rio
Paraná, $1 \mathrm{~km}$ below rio Baía estuary, upper rio Paraná basin, municipal district of Taquarussu, state of Mato Grosso do Sul, Brazil, 2245'S, 5320'W, 10-23 Mar 2004; MZUSP 108685 (female, $299 \mathrm{~mm}$ DW), same data as MZUSP 108684; MZUSP 108686 (male, $351 \mathrm{~mm}$ DW), same data as MZUSP 108684; MZUSP 108687 (male, $366 \mathrm{~mm} \mathrm{DW),} \mathrm{same} \mathrm{data} \mathrm{as} \mathrm{MZUSP}$ 108684; MZUSP 108688 (male, $238 \mathrm{~mm}$ DW), same data as MZUSP 108684; MZUSP 108689 (female, $337 \mathrm{~mm} \mathrm{DW),} \mathrm{same}$ data as MZUSP 108684; MZUSP 108690 (female, $311 \mathrm{~mm} \mathrm{DW),}$ same data as MZUSP 108684; MZUSP 108691 (female, $358 \mathrm{~mm}$ DW), same data as MZUSP 108684; MZUSP 108692 (male, 330 mm DW), same data as MZUSP 108684; MZUSP 108693 (female, $410 \mathrm{~mm}$ DW), same data as MZUSP 108684; MZUSP 108694 (male, $391 \mathrm{~mm}$ DW), same data as MZUSP 108684; MZUSP 108695 (male, $342 \mathrm{~mm}$ DW), same data as MZUSP 108684; MZUSP 108696 (male, $313 \mathrm{~mm} \mathrm{DW),} \mathrm{same} \mathrm{data} \mathrm{as} \mathrm{MZUSP}$ 108684; MZUSP 108697 (male, $238 \mathrm{~mm}$ DW), same data as MZUSP 108684; MZUSP 108698 (male, 281 mm DW), same data as MZUSP 108684; MZUSP 108699 (male, $240 \mathrm{~mm} \mathrm{DW),}$ same data as MZUSP 108684; MZUSP 108700 (male, $248 \mathrm{~mm}$ DW), same data as MZUSP 108684; MZUSP 108701 (male, 273 mm DW), same data as MZUSP 108684; MZUSP 108702 (female, $311 \mathrm{~mm}$ DW), same data as MZUSP 108684; MZUSP 108703 (female, $245 \mathrm{~mm}$ DW), same data as MZUSP 108684; MZUSP 108704 (male, $265 \mathrm{~mm}$ DW), same data as MZUSP 108684; MZUSP 108705 (male, $311 \mathrm{~mm} \mathrm{DW),} \mathrm{same} \mathrm{data} \mathrm{as} \mathrm{MZUSP}$ 108684; UMMZ 204551 (female, 366 mm DW), río Itenez, 9 km southwest of Costa Marques, state of Rondônia, Brazil, $12^{\circ} 32.4$ 'S, 64¹6.6’W, 18 Sep 1964.

Diagnosis. A species of Potamotrygon distinguished from congeners by the following combination of characters: dorsal disc with dark brown background coloration, with circular, reniform, oval, vermicular and/or rosette-like beige and orange spots, equal to or smaller than eye diameter; presence of one to three midrow of irregular spines on dorsal tail; presence of star-shaped, asymmetrical and minute dermal denticles, frequently with crown dichotomies, concentrated in central region of disc. In relation to congeners in the Paraná-Paraguay basin, $P$. falkneri is further distinguished from $P$. motoro by lacking on disc ocelli formed by strong black concentric rings, by the more flattened aspect of its disc, by presenting much smaller dermal denticles, and by having a greater number of tooth rows in upper jaw (30-45 vs. 23-32, respectively). From $P$. brachyura, $P$. falkneri is further distinguished by presenting a proportionally much longer tail (mean values $55 \%$ vs. $87.9 \%$ of DW, respectively), and in lacking a dorsal reticulate pattern. From $P$. histrix, $P$. falkneri is further separated by not presenting a dark grey dorsal and ventral disc, by having a slightly higher number of total vertebrae (means values 127 vs. 123, respectively), and by lacking developed dermal denticles on disc and tail margins. Potamotrygon falkneri is distinguished from the highly similar form recognized below as Potamotrygon sp. by not presenting its elongated distal tail extension posterior to sting, by having tail spines in one to three irregular rows (instead of a unique row), greater total pectoral radials (94$100 v s .90-93$ ), and spots that are not exclusively vermicular. 
Description. Morphometric and meristic data are shown in Tables 1-3.

External morphology. Disc oval (Figs. 1 and 2), only slightly longer than wide (DL 102.1-114.7\% of DW). Anterior margin of disc convex, with a small fleshy protuberance on snout. Posterior margins of disc also convex, their inner margins fused posteriorly to the dorsal surface of pelvic fins and tail base. Disc dorsoventrally compressed, relatively slender.
Anterior portion of disc with small, prominent, and oval shaped eyes. Spiracles oval and small (1.5 to 3 times eyes diameter) situated posterior to orbits and projecting obliquely from midline. Interspiracular distance greater (aproximately 1.5 times) than interorbital distance. Nasal curtain partially covering mouth and presenting small, fringed posterior ramifications. Mouth small (width 6.8-10.9\% DW); mouth opening relatively straight across and with five buccal papillae, two lateral and three central. One of three

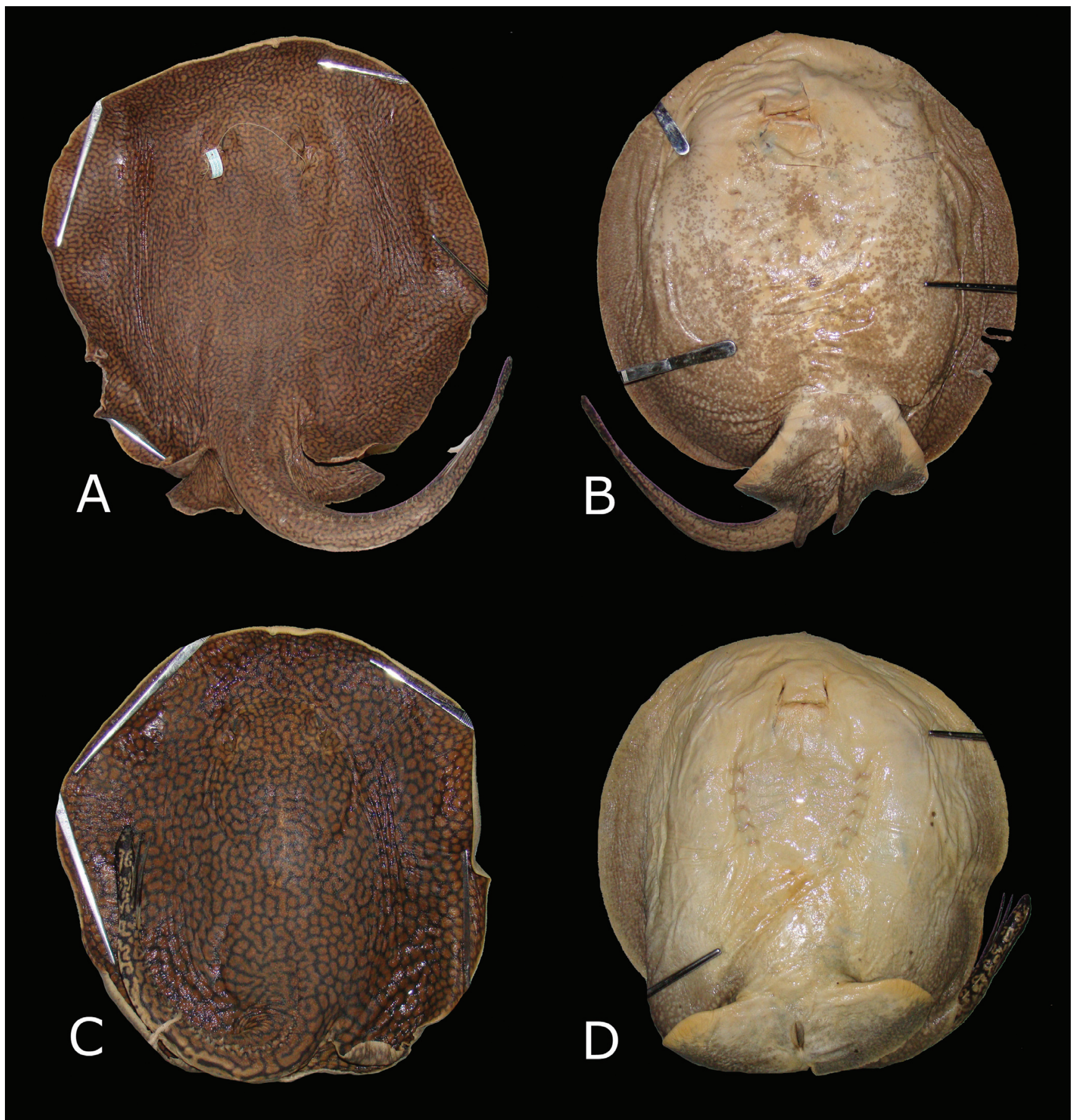

Fig. 1. Dorsal and ventral views of Potamotrygon falkneri specimens. A-B. NUP 2923, male, $380 \mathrm{~mm}$ DW (rio Cuiabazinho, State of Mato Grosso, Brazil); C-D. NUP 2917, female, $325 \mathrm{~mm}$ DW (same data as A and B). 
central papillae closer to lower jaw tooth plate. Mouth width and internarial space about equal. Labial ridges present. Teeth set in quincunx, with narrow and arched upper tooth plate, and wide and trapezoidal lower tooth plate. Tooth rows varying from $30-45$ on upper jaw and $29-43$ on lower jaw. Teeth relatively small, wider than long, and with flattened, elliptical, or lozenge-shaped crowns. Cusps rounded, pointed in males, or absent. Tooth plates presenting dignathic heterodonty. Teeth in lateral rows with elliptical crowns and generally lacking cusps. Teeth in central rows more robust, with lozenge-shaped crowns and rounded cusps. Sexual dimorphism present; some mature males with pointed cusps centrally on both tooth plates or on lower tooth plate only. Roots bilobed (holaulacorhize), with lobes separated by a shallow basal median groove.

Branchial basket relatively narrow and short, with space between first branchial slits $21.4-26.1 \%$ of DW and distance between first and last branchial slits 14.2-17.6\% of DW. Pelvic fin wider than long, partially covered by disc, and with posterior margin dorsally exposed posterior to disc margin.

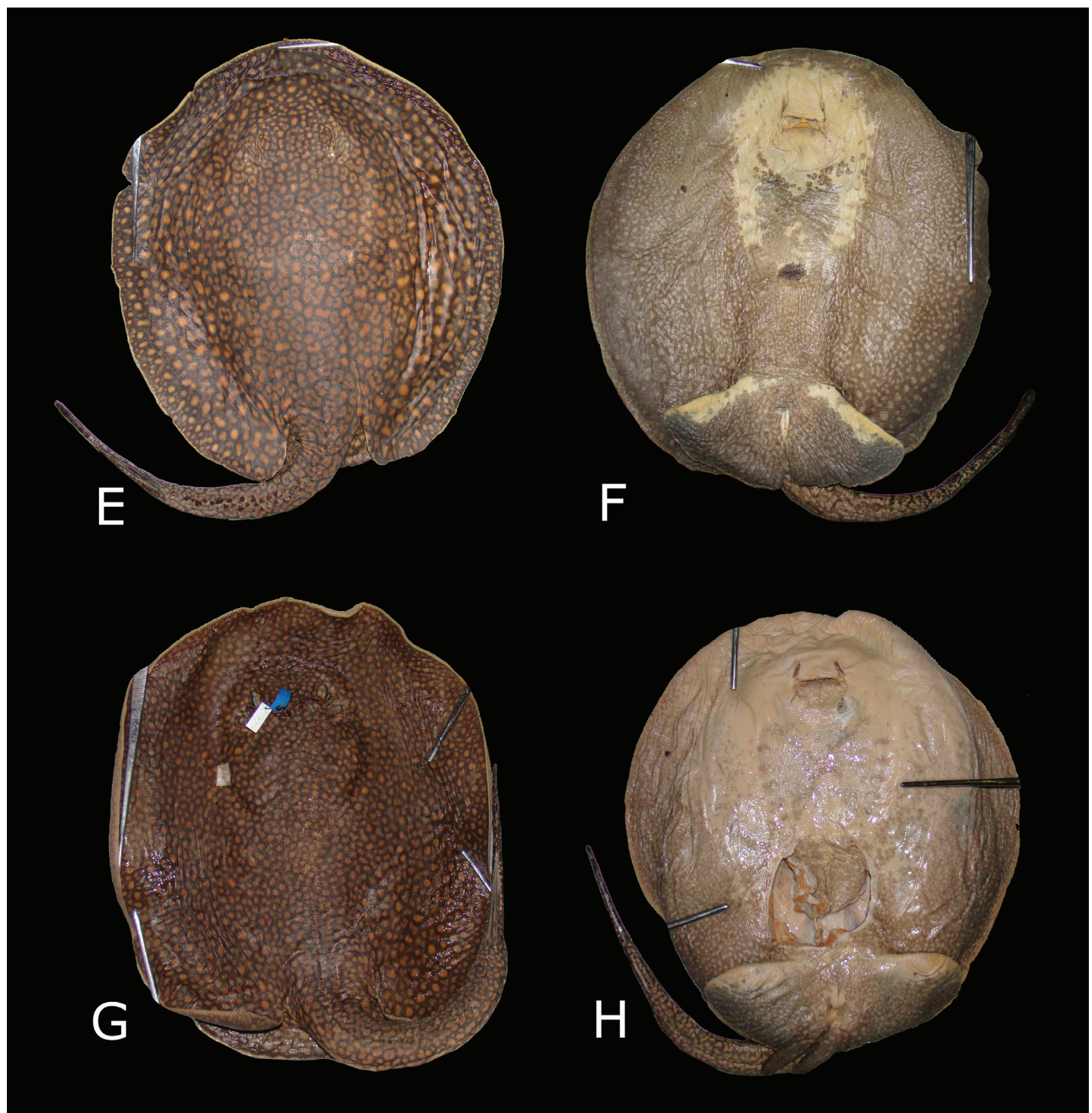

Fig. 1 (cont.). Dorsal and ventral views of Potamotrygon falkneri specimens. E-F. MZUSP 108684, female, $410 \mathrm{~mm}$ DW (rio Paraná, state of Mato Grosso do Sul, Brazil); G-H. MZUSP 108681, male, 350 mm DW (rio Manso, state of Mato Grosso, Brazil). 
Anterior margin of pelvic fin oblique in relation to midline. Clasper dorsoventrally depressed, wider at bases and narrowing distally, with rounded tips. Clasper groove beginning proximally at level of posterior margin of pelvics. Anterior half of clasper groove running obliquely from inner margin to outer margin of clasper. Posterior half curving inward at level of pseudosiphon, reaching midline and extending to clasper tip. Dorsal pseudosiphon well developed near inner edge, elliptical, and obliquely oriented in relation to midline. Ventral pseudosiphon also well developed, located at lateral distal edge of clasper.

Tail moderately elongated (tail length $87.9 \%$ of DW) and wide (mean width $13.3 \%$ of DW), with proximal portion slightly depressed dorsoventrally, and tapering from base to just

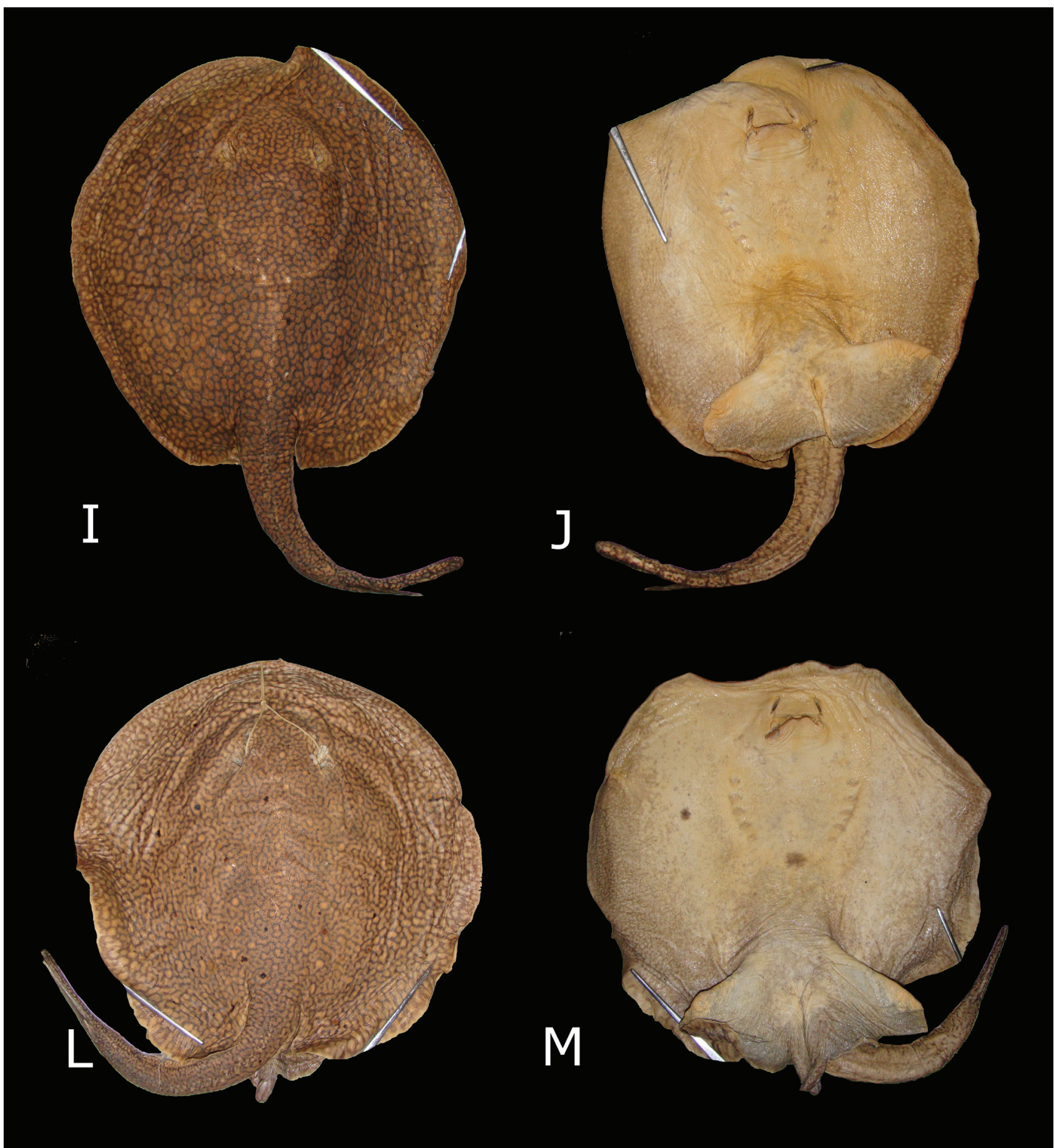

Fig. 1 (cont.). Dorsal and ventral views of Potamotrygon falkneri specimens. I-J. MZUSP 14578, female, 388 mm DW (rio Piquiri, rio Paraguai, Brazil); L-M. MZUSP 14848, male, 420 mm DW (Reservatório Taiamã, rio Paraguai, Brazil). 
posterior to sting insertion. Distal portion of tail, posterior to sting base, laterally compressed and presenting membranous dorsal and ventral caudal folds (these about 3-4 mm in height). Dorsal caudal fold originating underneath sting tip and extending to tail extremity. Ventral caudal fold originating at level ventral to sting base, extending to tail extremity. Serrated sting on dorsal tail single or paired, and relatively elongated (15.8-25.5\% of DW). Irregular midrows of spines on tail varying from one to three rows, and extending from base of tail to level of sting insertion. Enlarged spines on tail with rounded bases.

Dermal denticles. Males and females with similar dermal denticle morphology and distribution (Fig. 3). Disc with dermal denticles evenly scattered on midregion, from interorbital area to tail base. Denticles centrally positioned on disc with predominantly four to five crown ridges (cr), but varying from four to seven ridges. Crown ridges frequently showing crown dichotomies (cd). In dorsal view, denticles asymmetrical and star-shaped due to different lengths of crown ridges. Minute dermal denticles interspersed with larger denticles, exhibiting two to four crown ridges. Denticles in central region with rounded crown plates (cp).

Denticles more dispersed and smaller farther away from central region of disc, with crown ridges becoming less evident. Denticles on disc margins very rare, almost indiscernible. Dermal denticles also occur around and on margins of spiracle openings, as well as on orbits. Denticles devoid of crown ridges, but with pointed crowns, occur exclusively on spiracle superior margins, whereas denticles with two crown ridges and rounded crown plates occur on remaining regions. Pelvic fins and claspers devoid of dermal denticles. Denticles on dorsal tail small, devoid of crown ridges and with crowns sharply pointed, accompanying spine rows. Dorsal caudal fold presenting numerous very small dermal denticles; ventral caudal fold devoid of dermal denticles. Dermal denticles also occur on lateral tail region, from slightly anterior to sting base to distal tail extremity. Denticles more developed near sting base, becoming smaller closer to tail tip.

Coloration. Dorsal disc coloration variable (Figs. 1 and 2). Disc background color generally dark brown, but some specimens black or grey. Spots on background presenting circular, reniform, and oval shapes, with diameter equal to or smaller than eye diameter. Vermiculations and rosettes also present in some specimens. Spots varying in distribution and proximity dorsally on disc. Circular and reniform spots predominant but variable combinations also occur. In some specimens, vermiculations occur exclusively, and close together. Larger (older) specimens present very sparse reniform and rosette-like spots (Fig. 1N). Spots beige, light beige, brown, or orange. In specimens with dark brown or dark grey background, spots may be contoured by a fine dark band, resembling faint, irregular ocelli. In addition, small circular spots on disc edges present in most specimens. Pelvic fins dorsally similar to disc. Tail also with same basic color pattern, but usually with more vermiculations and rosettes.

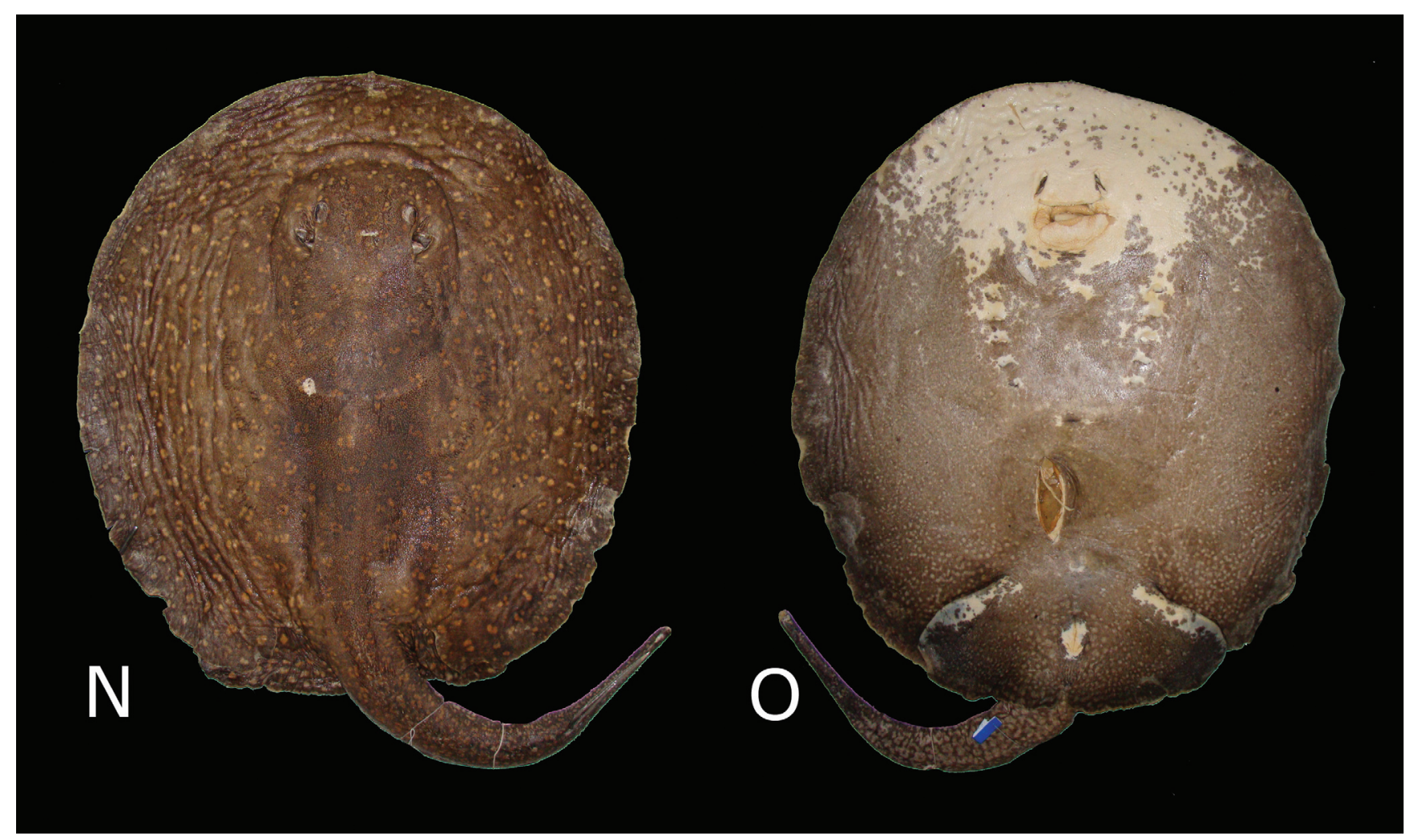

Fig. 1 (cont.). Dorsal and ventral views of Potamotrygon falkneri specimens. N-O. MZUSP 106267, female, 518 mm DW (rio Paraná, State of Mato Grosso do Sul, Brazil). 



Fig. 2. Paratype of Potamotrygon falkneri (MFA 235, female, $286 \mathrm{~mm} \mathrm{DL}$ ) in dorsal (A) and ventral (B) views (río Paraná, Província de Santa Fé, Argentina); (C) dorsal view of paratype of P. falkneri (MFA 235, as in A-B); (D) holotype in dorsal view of $P$. falkneri (MFA 236, female, $491 \mathrm{~mm}$ DL). C and D from M. Castex's archive in MFA; photograph not dated but probably from the early 1960 ‘s. 
Ventral medial region of disc white to off-white in majority of specimens. Within white background, small, rounded grey spots occur laterally and posterolaterally to gill slits. These spots are found scattered anteriorly, and coalesce posterioly. In some specimens, rounded and scattered grey spots also occur within the space between branchial slits. Border of disc margins grey, from level of nasal slits to posterior region of disc. Some specimens predominantly grey ventrally, with white embracing only a small portion of anterior region (larger specimens also present this pattern of ventral coloration, Fig. 1O). In these specimens, branchial slits surrounded by grey coloration. Light grey and white circular to vermicular spots may occur over grey background. Some specimens present variation in spot diameter, from bigger spots at margins to smaller spots on disc center, while others present spots of same size. In some cases, in region posterior to branchial slits, a black oval spot occurs of varying shape and intensity. Pelvic fins with predominantly dark grey ventral coloration, presenting small circular, reniform and vermicular white spots. White coloration restricted to fine bands on anterior region of fins. Cloaca surrounded by white coloration. Ventral tail region with a disorganized reticulated pattern, formed by irregular light grey and white vermicular spots, over a grey background. Distal extremity of tail black, with small, irregular white spots.

Sensory canal system. Particular characteristics of ventral lateral-line canals in Potamotrygon falkneri include (Fig. 4): suborbital loop (sol), originated from the infraorbital canal (ioc), far from hyomandibular canal (hyoc) anteriorly, and projecting towards middle portion of disc; presence of an elevated number of anterior subpleural tubules (ast) projecting from hyomandibular canal on anterior-most part of the disc; hyomandibular jugular component (hjc) extends laterally to the branchial slits, lightly undulated; the jugular canal (jug) presents pronounced undulations adjacent to the branchial slits; hyomandibular subpleural component (hsc), extends laterally to the disc margins, devoid of any evident undulation; mandibular canal (man) short, situated posterior to mouth, extending posterolateraly and with pronounced undulations on its proximal portion; infraorbital loop (iol) with tenuous undulations at its internal corners; orbitonasal component of supraorbital canal (ocs) rather homogeneous; final ascendant part of suborbital component (sci) originates from infraorbital canal highly undulated; prenasal loop (pnl) short and straight; posterior subpleural tubule (pst) usually single and projecting obliquely from subpleural loop (spl) to posterolateral margin of disc. Some specimens present both orbitonasal component of supraorbital canal and final ascendant part of suborbital component of infraorbital canal, slightly undulated.

Neurocranium. Neurocranium somewhat elongated (Fig. 5), with elliptic and ventrolaterally expanded nasal capsules (nc). Anterior margins of nasal capsules convex, presenting a medial notch in between. An internal, ventromedial sept divides the nasal capsules. Preorbital processes (prp) well developed and curved backwards, situated above the condyle for the antorbital cartilage. Postorbital processes (pop) shelf-like, anterolaterally expanded and located on dorsolateral corners of otic region. Supraorbital processes (sp) small and triangular, situated slightly anterior to postorbital processes. Supraorbital crests (soc) originating posteriorly to preorbital processes and extending posteriorly to postorbital processes. Antorbital cartilage condyles (anc) on posterolateral extremities of nasal capsules. Precerebral fontanelle (pcf) and frontoparietal fontanelle (fpf) partially separated by a moderately developed transverse bridge, the

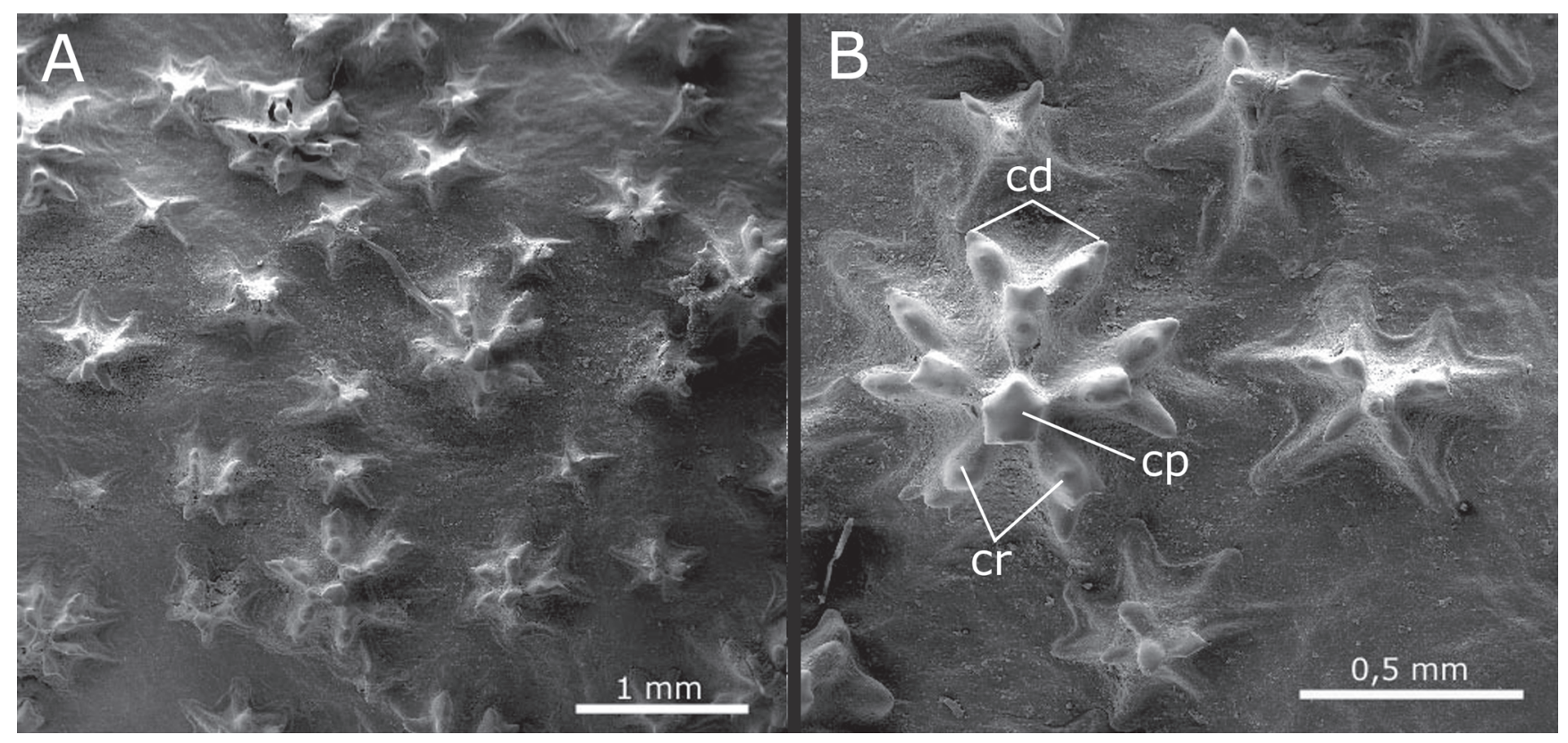

Fig. 3. Dermal denticles of Potamotrygon falkneri in dorsal view, from mid region of back; A. Denticle arrangement; B. Individual dermal denticle amplified; cd, crown dichotomy; cp, crown plate; cr, crown ridge. 
epiphysial bar. Together, fontanellae keyhole shaped, circular anteriorly and narrowing posteriorly. Hyomandibular facet (hmdf) located on ventrolateral corner of otic region and corresponds to an oval, horizontally positioned depression. Dorsally, neurocranium presents anterior foramen for preorbital canal (afpc) at base of preorbital process, and several foramina for the superficial ophthalmic nerve (sup) piercing supraorbital crest. Paired internal carotid artery foramina (icaf) ventrally situated near lateral edges of neurocranium. Eye-stalk (es) origin oval, originating on lateral orbital wall just posterior to wide and oval optic nerve foramen (II). Oculomotor nerve foramen (III) dorsal to eyestalk. A bridge-like lateral commisure (lc) present external to hyomandibular branch of facial nerve foramen (VII). Posterior foramen for preorbital canal (pfpc) also located dorsally, at junction of nasal capsule and orbit. Anterior cerebral vein foramen (acvf) located anterodorsal to optic nerve foramen. The efferent spiracular artery foramen (esaf) posteroventral to eye-stalk. Interorbital vein foramen (ivf) positioned posterior to base of eye-stalk. Relatively wide orbital fissure (obf) located above and slightly anterior to hyomandibular branch of facial nerve foramen. Foramen magnum (fm) circular. Articular surface (as) and occipital condyles (oc) for articulation with synarcual ventral to foramen magnum. Vagus nerve foramen (X) situated laterally to foramen magnum; glossopharyngeal nerve foramen (IX) located dorsolaterally in relation to occipital condyles. Two pairs of lymphatic foramina present dorsally in otic region, the anterior endolymphatic foramen (elf) and posterior perilymphatic foramen (plf).

Hyomandibular arch. Hyomandibular cartilages (hyo) elongated, laterally compressed, articulating with hyomandibular facet on otic region of neurocranium, from where they project anterolaterally (Fig. 6). Hyomandibula articulates with Meckel's cartilage (Mc) by means of robust hyomandibular-Meckelian ligament. Embedded within ligament occur anterior (aac) and posterior angular cartilages (pac); anterior angular more robust than posterior. Meckel's cartilage and palatoquadrate (pq) flattened; antimeres of both arches not fused symphysially, separated by short space containing strong horizontal ligaments. Posteriorly, between palatoquadrates and Meckel's cartilages occurs a circular aperture formed by inferior surface of palatoquadrate and superior portion of Meckel's cartilage. Palatoquadrate slightly arched, relatively straight on dorsal border and with
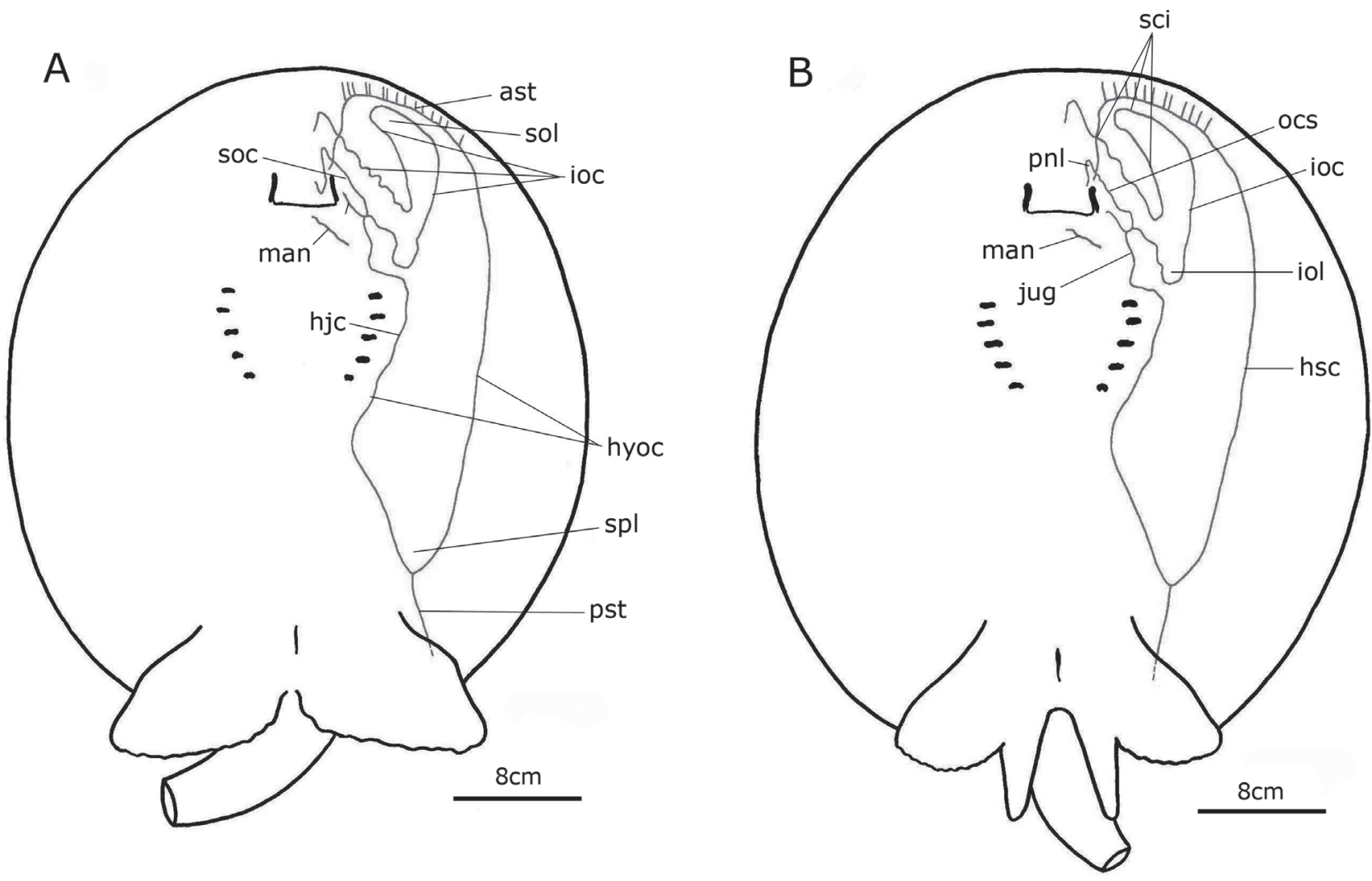

Fig. 4. Ventral lateral line canal system of Potamotrygon falkneri. (A) MZUSP 106258, female, $292 \mathrm{~mm}$ DW; (B) MZUSP 106262, male, $273 \mathrm{~mm}$ DW; ast, anterior subpleural tubules; hjc, hyomandibular jugular component; hsc, hyomandibular subpleural component; hyoc, hyomandibular canal; ioc, infraorbital canal; iol, infraorbital loop; jug, jugular canal; man, mandibular canal; nas, nasal canal; ocs, orbitonasal component of supraorbital canal; pnl, prenasal loop; pst, posterior subpleural tubule; sci, suborbital component of infraorbital canal; soc, supraorbital canal; sol, suborbital loop; spl, subpleural loop. 
pronounced curvature on ventral margin. Posterior triangular projections (ptp) present close to lateral edges of palatoquadrates. Palatoquadrates become progressively narrow in direction of midline. Meckel's cartilages more arched than palatoquadrates, slender near symphysis, with evident rounded posterior margins, and with a pronounced concavity on inner corners that articulate with palatoquadrates. A marked curvature present on external aspect of Meckel's cartilage for attachment of robust hyomandibular ligament. Ventrolateral processes (vlp) projecting from both extremities of Meckel's cartilages.

Synarcual. The cervicothoracic or anterior synarcual articulates with neurocranium between occipital condyles


Fig. 5. Dorsal (A), ventral (B), lateral (C) and posterior (D) views of neurocranium of Potamotrygon falkneri (MZUSP 106265, male, $231 \mathrm{~mm} \mathrm{DW);} \mathrm{acvf,} \mathrm{anterior} \mathrm{cerebral} \mathrm{vein} \mathrm{foramen;} \mathrm{afpc,} \mathrm{anterior} \mathrm{foramen} \mathrm{for} \mathrm{preorbital} \mathrm{canal;} \mathrm{anc,} \mathrm{antorbital} \mathrm{cartilage}$ condyle; as, articular surface; elf, endolymphatic foramen; es, eye-stalk; esaf, efferent spiracular artery foramen; fpf, frontoparietal fontanelle; fm, foramen magnum; hmdf, hyomandibular facet; icaf, internal carotid artery foramen; ivf, interorbital vein foramen; lc, lateral commisure; nc, nasal capsule; obf, orbital fissure; oc, occipital condyle; pcf, precerebral fontanelle; pfpc, posterior foramen for preorbital canal; plf, perilymphatic foramen; pop, postorbital process; pq, palatoquadrate; prp, preorbital process; soc, supraorbital crest; sp, supraorbital process; sup, superficial ophthalmic nerve foramina; II, optic nerve foramen; III, oculomotor nerve foramen; VII, hyomandibular branch of facial nerve foramen; IX, glossopharyngeal nerve foramen; $X$, vagus nerve foramen. 


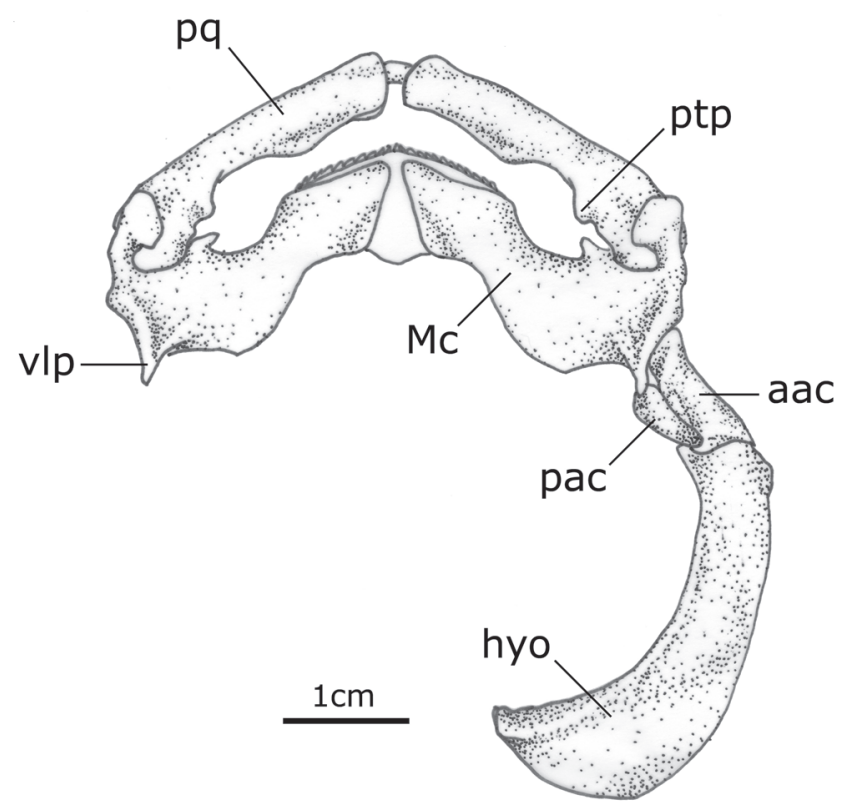

Fig. 6. Dorsal view of hyomandibular arch of Potamotrygon falkneri (MZUSP 106265, male, $231 \mathrm{~mm}$ DW); aac, anterior angular cartilage; hyo, hyomandibula; Mc, Meckel's cartilage; pac, posterior angular cartilage; pq, palatoquadrate; ptp, posterior triangular projection; vlp, ventrolateral process.

by a median, anterior protuberance from anteroventral extremity of synarcual, the odontoid process (otp). The medial crest (mdc) corresponds to an anteroposterior dorsal crest present on synarcual (Fig. 7). Spinal nerve foramina (snf) present along lower portion of synarcual, adjacent to lateral bulge of spinal nerve canal (snc). A lateral stay (ls) projects dorsally from lateral wall of synarcual. Suprascapulae firmly fused posterodorsally on synarcual through a socket and condyle articulation (asp) with scapular processes.

Pectoral girdle. Coracoid cartilage dorsoventrally flattened located ventral to synarcual (Fig. 8). Several foramina for muscles, nerves and condyles for the pectoral pterygia are located on the lateral surface of pectoral girdle. The procondyle (pc), mesocondyle (msc) and metacondyle (mtc) are situated along the horizontal axis of the scapular cartilage. Anterodorsal fenestrae (adf) occur dorsal to the condyles, and anteroventral fenestrae (avf) occur ventrally. Posterodorsal (pdf) and posteroventral (pvf) fenestrae are also present. The anterior fenestrae have wider apertures in relation to the posterior ones. The scapular processes, comprising the dorsal tips of pectoral girdle, firmly articulate with lateral faces of synarcual.

Pelvic girdle. The pelvic girdle (Fig. 9) consists of a puboischiadic bar (pib), a median prepelvic process (ppp), iliac processes (ip), lateral prepelvic processes (lpp), and isquial processes (isp). The puboischiadic bar is slightly arched, with lateral extremities widened where the three obturator formanina (of) are located. The prepelvic process consists of an anterior elongated projection. Robust and posterodorsally directed iliac processes are present on the lateral extremities of the puboischiadic bar. Triangular and well developed isquial processes are located on the inner corners of pelvic girdle posterior concavity. Short, robust and anterolaterally directed lateral prepelvic processes are present on each anterolateral corner of puboischiadic bar.

Claspers. Clasper skeleton (Fig. 10) consists of the following cartilages: dorsal marginal (dm), ventral marginal (vm), dorsal terminal 2 (dt2), accessory terminal (at), ventral terminal (vt), axial cartilage (ax), two basal segments (b1 and b2) and a single beta cartilage (be). Dorsal terminal 2 long, relatively narrow and oval-shaped with a groove present along its proximal portion. Outer edges of dorsal marginal and dorsal terminal 2 forming the clasper groove externally. Inner edge of posterior portion of dorsal marginal forming dorsal pseudosiphon externally. Accessory terminal elongated and fusiform, underlying dorsal terminal 2 , and forming ventral pseudosiphon externally from its outer edge. Ventral terminal broad, long and oval. Ventral marginal long and narrow, with pronounced anterior tip. Axial cartilage straight, depressed anterioly and distally cylindrical, tapering toward extremity. First basal segment (b1) connecting to basipterygium and second basal segment (b2) linked to proximal part of axial cartilage. Beta cartilage originating at first basal segment and distally articulated with dorsal marginal.

Geographical distribution. Potamotrygon falkneri occurs in the Paraná-Paraguay (Manso, Aricá-Mirim, Casca, Piquiri, Cuiabá, and upper Paraná Rivers) and La Plata (lower Paraná and Colastiné Rivers, Santa Fé stream, and lago Setúbal) basins, and in the upper Amazon drainage in Bolívia (Madre de Díos, Guaporé, and Beni Rivers), Peru (Madre de Díos and Marañon Rivers), and Brazil (rio Solimões) (Fig. 11).

Remarks. Specimens of Potamotrygon in the Museu Florentino Ameghino (MFA, Santa Fé, Argentina) were precariously preserved, having lost their original identification tags made of small, circular aluminum plates. The holotype of Potamotrygon menchacai (MFA 289, an adult male) and the paratype of Potamotrygon castexi (MFA 288 , also an adult male) - the only remaining type-material of these nominal species still expected to be available could not be found during a visit to the MFA. An attempt was made to identify type-material based on the measurements presented in their original descriptions, but their coloration was usually completely faded, and parts of the disc and tail were damaged or missing, all of which made locating type-material on the basis of secondary information very difficult. Rosa (1985) comments on the unfortunate condition of the paratype of $P$. castexi (MFA 288) in the early 1980 's, exemplified by the numerous damaged parts of disc, broken tail, and missing caudal sting and jaws. 
Although the holotype of $P$. menchacai was also examined by Rosa and seemed to be well preserved at that time, it also could not be found during our visit to the MFA.

The holotype of Potamotrygon castexi (MACN 5777), originally deposited in the Museo Argentino de Ciencias Naturales Bernardino Rivadavia (Buenos Aires) was previously reported to be lost (Rosa, 1985), which was confirmed during our visit to that institution. According to Rosa (1985), the holotype dried in storage at MACN and could have been discarded. A paratype (ILAFIR 100), previously deposited in the Instituto Latino Americano de Fisiologia
Reprodutiva (Universidad del Salvador, San Miguel), and subsequently transferred to MACN, was also not found during our visit.

Although collection numbers of the two type-specimens of P. falkneri (Fig. 2) were not given in the original description, we do not follow Castex (1964) in recognizing MFA 235 as the holotype of this species. According to the ICZN (1999, Chapter 16, Articles 73.1.1 and 73.1.3), the holotype of a new nominal species-group taxon can only be fixed in the original publication and by the original author using the expressions "holotype or "the type" (or equivalent

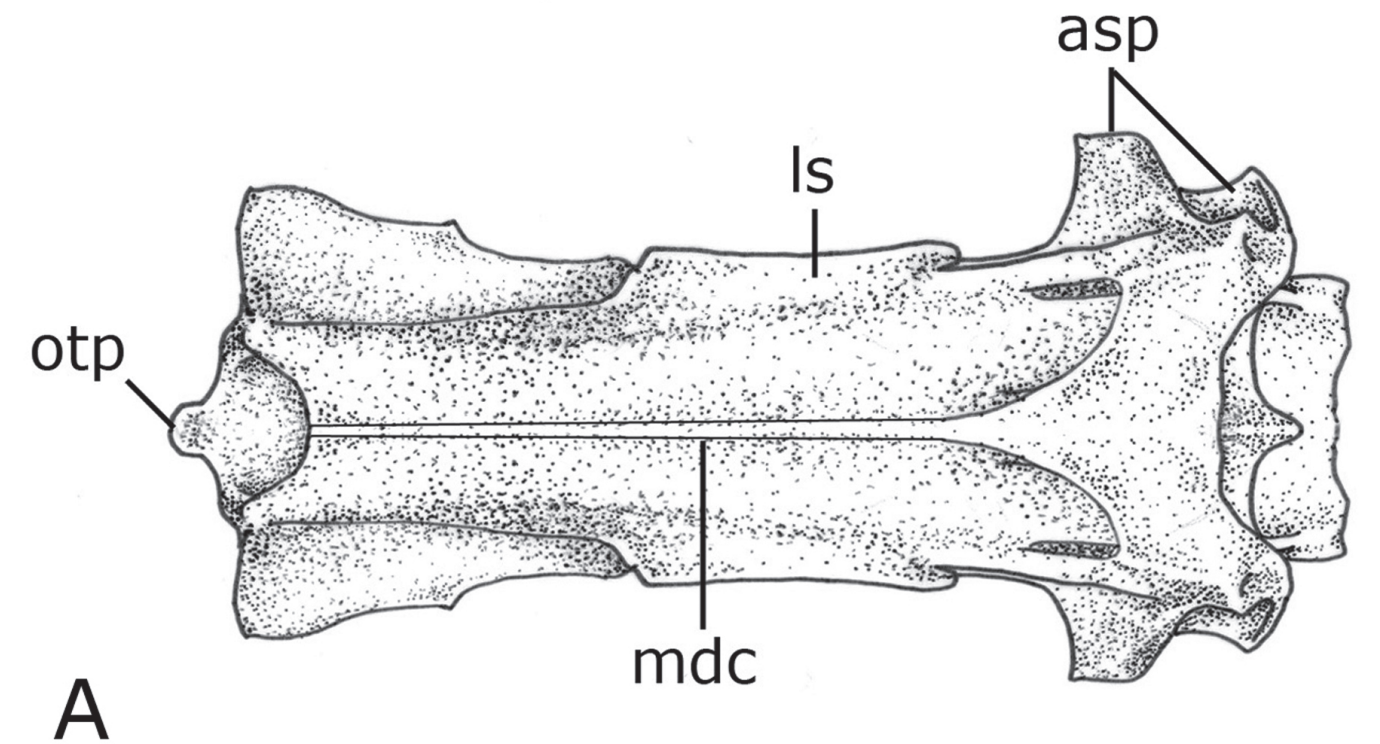

$1 \mathrm{~cm}$

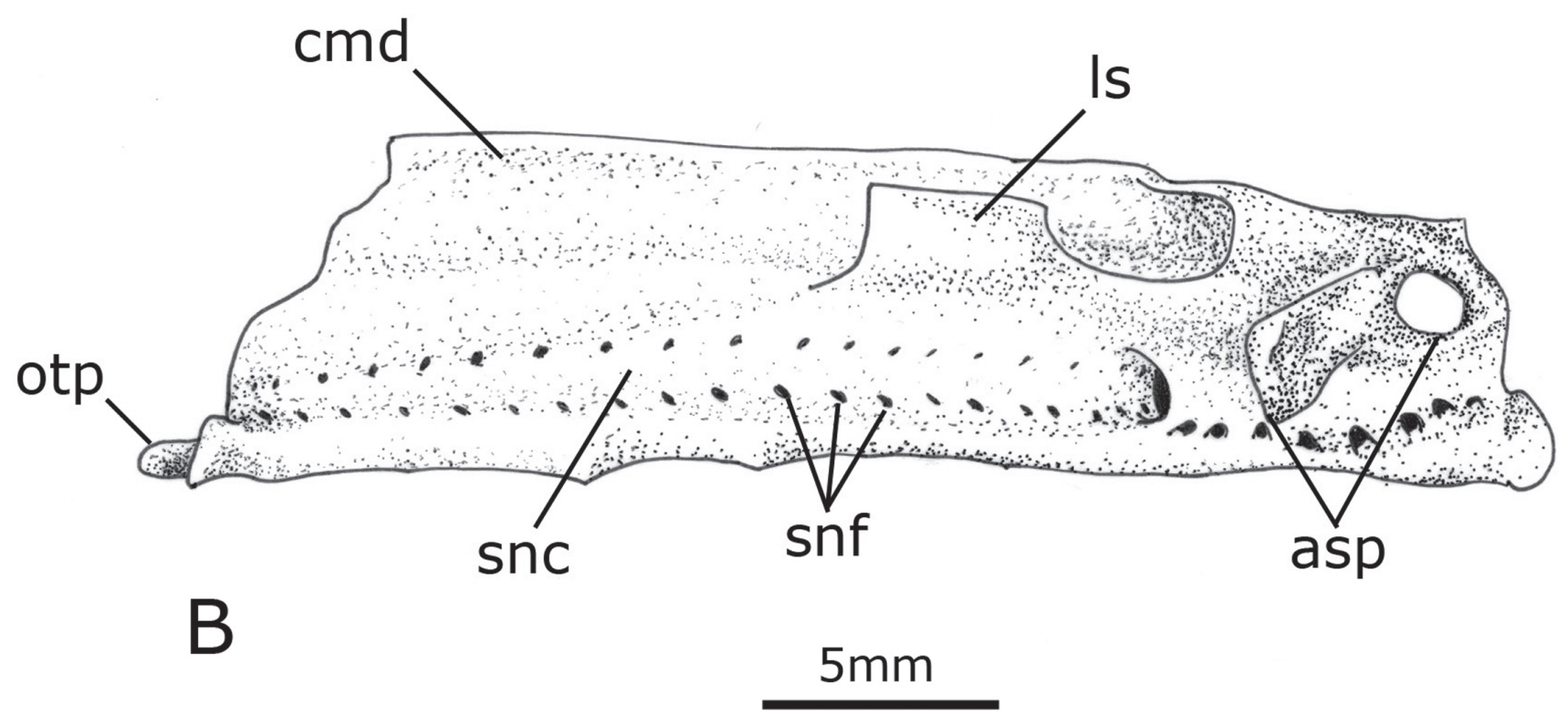

Fig. 7. Dorsal (A) and lateral (B) views of synarcual cartilage of Potamotrygon falkneri (MZUSP 106265, male, $231 \mathrm{~mm}$ DW); asp, articular surface for scapular process; 1s, lateral stay; mdc, medial crest; otp, odontoid process; snc, spinal nerve canal; snf, spinal nerve foramen. 
Table 1. Morphometric data of Potamotrygon falkneri from Paraná-Paraguay basin. Data are expressed in milimeters and percentages of disc width (\% DW). SD $=$ Standard deviation.

\begin{tabular}{lcccccc}
\hline \multicolumn{1}{c}{ Measurements } & Paratype & $\mathrm{n}$ & \multicolumn{2}{c}{ Range } & Mean & SD \\
\hline & $\mathrm{mm}$ & & $\mathrm{mm}$ & $\% \mathrm{DW}$ & \%DW & $\% \mathrm{DW}$ \\
Total length & 523 & 65 & $415-890$ & $117.8-198.2$ & 178.9 & 4.6 \\
Disc length & 286 & 65 & $245-578$ & $102.1-114.7$ & 107.2 & 0.3 \\
Disc width & - & 65 & $230-518$ & - & - & 0.0 \\
Interorbital space & 38 & 65 & $25-75$ & $11.0-15.1$ & 11.8 & 0.3 \\
Interspiracular space & 55 & 65 & $42-110$ & $15.9-21.9$ & 18.0 & 0.4 \\
Eye length & - & 65 & $7-14$ & $2.3-4.3$ & 3.3 & 0.1 \\
Spiracle length & - & 65 & $16-48$ & $6-8.9 .0$ & 7.4 & 0.0 \\
Sting length & 68 & 65 & $42-91$ & $15.8-25.5$ & 20.4 & 0.3 \\
Sting width & 5 & 65 & $3-9$ & $1.2-3.0$ & 1.8 & 0.1 \\
Preorbital length & - & 48 & $49-133$ & $21.0-26.5$ & 24.5 & 0.1 \\
Prenasal length & - & 65 & $33-88$ & $13.0-20.8$ & 17.0 & 0.5 \\
Preoral length & - & 65 & $45-113$ & $17.4-27.6$ & 22.2 & 0.3 \\
Internarial space & - & 65 & $18-44$ & $7.0-10.0$ & 8.4 & 0.0 \\
Mouth width & - & 65 & $18-53$ & $6.8-10.9$ & 8.6 & 0.3 \\
Space between $1^{\text {st }}$ branchial slits & 71 & 65 & $51-120$ & $21.4-26.1$ & 23.8 & 0.0 \\
Space between 5 $5^{\text {th }}$ branchial slits & 49 & 65 & $35-88$ & $14.6-18.1$ & 16.2 & 0.2 \\
Branchial basket length & 41 & 65 & $35-81$ & $14.2-17.6$ & 15.7 & 0.0 \\
Pelvic fin length & 74 & 65 & $48-123$ & $18.6-29.0$ & 24.0 & 0.2 \\
Pelvic fin width & - & 29 & $116-293$ & $31.8-64.6$ & 57.0 & 2.4 \\
Clasper external edge length & - & 29 & $13-55$ & $5.4-15.0$ & 12.7 & 1.1 \\
Clasper internal edge length & - & 65 & $35-120$ & $15.0-29.8$ & 24.8 & 1.9 \\
Cloaca to tail tip & 255 & 65 & $218-462$ & $75.3-104.3$ & 87.9 & 2.1 \\
Tail width & 38 & 65 & $31-90$ & $9.0-16.9$ & 13.3 & 0.6 \\
Snout to cloaca & 244 & 65 & $189-460$ & $71.5-97.4$ & 87.3 & 1.0 \\
Axilla pectoral to posterior edge of pelvic fin & 40 & 65 & $28-80$ & $11.0-17.8$ & 13.7 & 0.2 \\
Cloaca to sting & 153 & 65 & $112-330$ & $44.0-81.9$ & 52.0 & 2.3 \\
\hline
\end{tabular}

expression; holotype is the specimen fixed by original designation). This is not the case of specimen MFA 235 as it does not correspond with the description of the specimen figured as "type" in the original description (not matching in size). Specimen MFA 235 is probably part of the type series, as it is indicated in the collection list at MFA as "type" (and also according to Castex, 1964), but should therefore be treated as a paratype (ICZN 1999, Chapter 16, Article 72.4.5). Note that this interpretation is in accordance with Rosa (1985), who previously identified specimen MFA 236 as the holotype (which is presently lost), on the basis that MFA 235 did not correspond with the specimen figured as "type" in the original description of Castex \& Maciel (1963). According to Rosa (1985), the identification of the holotype was based on the comparison of the measurements given for the type with those of specimen MFA 236, and by matching details of the color pattern of MFA 236 with the photograph of the type in the original description. Specimen MFA 235 (paratype), however, is the only remaining typespecimen of $P$. falkneri, and is in a poor state of conservation. Some parts of the disc are damaged, such as a large portion of the left side of the disc. The jaws were removed, and both dorsal and ventral coloration have become dark brown due to what appears to be putrefaction. The paratype could be confidently identified, however, due to its metal tag that was still attached to the dorsal surface of disc, although barely legible due to corrosion. Measurements of this specimen closely correspond with those given for the second specimen in the original description, and also agree with it in gender.

\section{Discussion}

\section{Morphological analysis}

Two discrete species were uncovered by our analysis of external morphology and morphometrics. The first species was composed of specimens that can be assigned to the nominal species Potamotrygon falkneri, Potamotrygon castexi, and Potamotrygon menchacai. The second species was composed of specimens of a putative new species treated here as Potamotrygon sp (Figs. 12 and 13; see separate section below). As expected, coloration was not very helpful to isolate discrete groups of specimens within the former species due to their great chromatic variation; but the latter group presented a more uniform pattern composed exclusively of relatively slender and united vermicular markings. Presence of labial folds and proportional measurements of eyes and spiracles were also not effective to separate distinct species (characters useful in distinguishing other species of Potamotrygon). The claspers did not present notorious distinctions in relation to their general shape and external morphology, such as the configuration of the clasper groove and dorsal and ventral pseudosiphon, which seemed to vary only slightly in size, but not consistently. Additionally, the ventral sensory canal system and internal anatomy based on skeletal structures presented only minimal variation, and therefore could not be applied to discriminate distinct species.

However, morphology and arrangement of tail spines and dermal denticles were more useful to separate both species. In the first (P.falkneri), spines on dorsal tail region present a variable organization, and dermal denticles present a greater 
Table 2. Morphometric data of Potamotrygon falkneri from the upper Amazon basin. Data are expressed in millimeters and percentages of disc width $(\% \mathrm{DW})$. $\mathrm{SD}=$ Standard deviation.

\begin{tabular}{lccccc}
\hline \multicolumn{1}{c}{ Measurements } & $\mathrm{n}$ & \multicolumn{2}{c}{ Range } & Mean & SD \\
\hline & & $\mathrm{mm}$ & $\% \mathrm{DW}$ & $\% \mathrm{DW}$ & $\% \mathrm{DW}$ \\
Total length & 10 & $522-815$ & $174.6-202.3$ & 187.5 & 8.6 \\
Disc length & 10 & $234-488$ & $103.7-113.0$ & 108.2 & 3.4 \\
Disc width & 10 & $225-432$ & - & - & - \\
Interorbital space & 10 & $23-58$ & $10.2-13.5$ & 12.3 & 0.9 \\
Interspiracular space & 10 & $38-76$ & $16.6-18.9$ & 17.5 & 0.7 \\
Eye length & 10 & $12-26$ & $3.9-8.7$ & 5.8 & 1.4 \\
Spiracle length & 10 & $24-39$ & $7.4-10.7$ & 9.0 & 1.1 \\
Sting length & 10 & $61-96$ & $20.0-30.6$ & 23.7 & 3.1 \\
Sting width & 10 & $6-9$ & $1.6-2.6$ & 2.0 & 0.3 \\
Preorbital length & 10 & $55-111$ & $23.3-27.5$ & 25.3 & 1.4 \\
Prenasal length & 10 & $42-81$ & $15.3-18.9$ & 16.9 & 1.2 \\
Preoral length & 10 & $56-110$ & $21.2-25.6$ & 23.5 & 1.4 \\
Internarial space & 10 & $19-38$ & $7.7-9.3$ & 8.4 & 0.6 \\
Mouth width & 10 & $24-47$ & $8.5-11.7$ & 10.2 & 1.1 \\
Space between 1 st branchial slits & 10 & $55-111$ & $23.2-26.2$ & 24.5 & 1.1 \\
Space between 5 ${ }^{\text {th }}$ branchial slits & 10 & $36-80$ & $16.0-19.7$ & 17.7 & 1.1 \\
Branchial basket length & 10 & $29-68$ & $12.9-16.4$ & 15.1 & 1.1 \\
Pelvic fin length & 10 & $47-104$ & $20.7-27.3$ & 24.2 & 2.3 \\
Pelvic fin width & 10 & $108-260$ & $48.0-67.4$ & 58.1 & 6.1 \\
Clasper external edge length & 10 & $38-60$ & $11.3-14.4$ & 13.5 & 1.2 \\
Clasper internal edge length & 10 & $29-111$ & $12.9-26.7$ & 23.7 & 4.9 \\
Cloaca to tail tip & 10 & $196-406$ & $68.5-110.2$ & 93.5 & 12.7 \\
Tail width & 10 & $30-95$ & $13.3-25.4$ & 17.8 & 3.3 \\
Snout to cloaca & 10 & $190-391$ & $84.4-92.5$ & 89.2 & 2.7 \\
Pectoral axil to posterior edge of pelvic fin & 10 & $29-71$ & $12.3-17.4$ & 14.7 & 2.0 \\
Cloaca to sting & 10 & $150-276$ & $50.3-64.3$ & 56.3 & 4.5 \\
\hline
\end{tabular}

number of crown ridges and crown dichotomies. The second species (Potamotrygon sp.) has spines on dorsal tail disposed in a single row that is more uniformly arranged, and dermal denticles have fewer crown ridges, and rarely have crown dichotomies.

\section{Identification of Potamotrygon falkneri}

The vast majority of specimens examined in this study had diagnostic characters mentioned in the original description of Potamotrygon falkneri, and also in the further description provided by Castex (1964), such that they could be unequivocally identified as belonging to this species. These characters are: subcircular disc, which is slightly longer than wide; relatively small eyes (compared to P. motoro, for example); presence of minuscule star-shaped denticles on the central region of the disc, with rest of disc smooth; mouth with five buccal papillae; small teeth devoid of cusps in females, with males having central teeth in upper and lower jaws with pointed (triangular) cusps; tail spines with tips directed posteriorly; tail without lateral denticles on its proximal half; dorsal coloration dark brown with numerous circular or elliptical yellowish spots; ventral portion of middisc white with grayish coloration laterally. The paratype was not very helpful to further define $P$. falkneri due to its precarious condition, insofar as few external characteristics and scarce morphometric data were obtained from it.

A much greater variation was observed in our material than that reported by Castex \& Maciel (1963) in the original description of $P$. falkneri, principally in disc coloration. This is due to the fact that the original description was based on only two specimens from the same locality. Furthermore, in the original description, other characters were analyzed only superficially (e.g., teeth), few morphometric data were taken into account, and meristic data are altogether absent. The general characteristics of $P$. falkneri in relation to coloration observed in the present study are: disc background generally dark brown, but in few cases with grey and blackish colorations; spots circular, reniform, oval, vermicular, and rosette-like, and usually equal or smaller than eye diameter; spots varying in disposition and combination dorsally on disc; spots beige, orange, and brown. Another character that presented great variation was the arrangement of spines on dorsal tail. In examined specimens, dorsal tail spines formed one to three irregular rows. This variable disposition of spines on dorsal tail was found even among specimens showing

Table 3. Meristic data of Potamotrygon falkneri. SD = Standard deviation.

\begin{tabular}{lcccc}
\hline \multicolumn{1}{c}{ Counts } & $\mathrm{n}$ & Range & Mean & SD \\
\hline Precaudal vertebrae & 18 & $26-31$ & 28.8 & 1.4 \\
Caudal vertebrae & 17 & $92-105$ & 98.1 & 3.4 \\
Total vertebrae & 17 & $120-136$ & 127.0 & 3.7 \\
Synarcual vertebrae & - & - & - & - \\
Diplospondylous vertebrae & 17 & $87-100$ & 94.4 & 3.9 \\
Upper tooth rows & 18 & $30-45$ & 36.4 & 4.4 \\
Lower tooth rows & 18 & $29-43$ & 36.3 & 4.1 \\
Propterygial radials & 18 & $42-48$ & 46.2 & 1.5 \\
Mesopterygial radials & 18 & $13-15$ & 13.7 & 0.6 \\
Metapterygial radials & 18 & $35-38$ & 37.0 & 0.9 \\
Total pectoral radials & 18 & $94-100$ & 96.9 & 1.5 \\
Pelvic radials (male) & 13 & $21-23$ & 21.7 & 0.6 \\
Pelvic radials (female) & 5 & $25-27$ & 25.8 & 0.8 \\
\hline
\end{tabular}


identical disc coloration and from the same locality.

Dermal denticles, in general, were given little importance by Castex \& Maciel (1963), not only in the original description but in other papers as well (Castex 1964, Castex 1967a). Castex \& Maciel (1963) refer to them as "star ossifications" and do not provide morphological details, such as number of crown ridges and general aspect of crowns, commenting only on their central distribution on disc. But subsequent to the original description of P. falkneri, in a paper addressing only dermal denticles in potamotrygonids, Castex (1967a) notes that males and females of this species present not only different denticle morphologies but a different intensity of the denticle cover (relative number of denticles). Yet no morphological description of denticles was provided by Castex (1967a), nor examples of their alleged morphological differentiation or relative frequency between males and females, except in the rather poor photographs and drawings. His photos, amplifications of single male and female dermal denticles, show differences in the number of crown ridges and presence of crown dichotomies, but this discrepancy may be due to variation within an individual. According to our results, and in contrast to Castex (1967a), distinct morphologies and frequencies of dermal denticles were not observed between males and females of $P$. falkneri.

Characters analyzed in the present study were also examined in the systematic revision of potamotrygonids by Rosa (1985). Rosa's account was based on fewer specimens of $P$. falkneri (less comparative material was then available), but he did a much greater and more thorough analysis compared to the original description of Castex \& Maciel (1963), including a

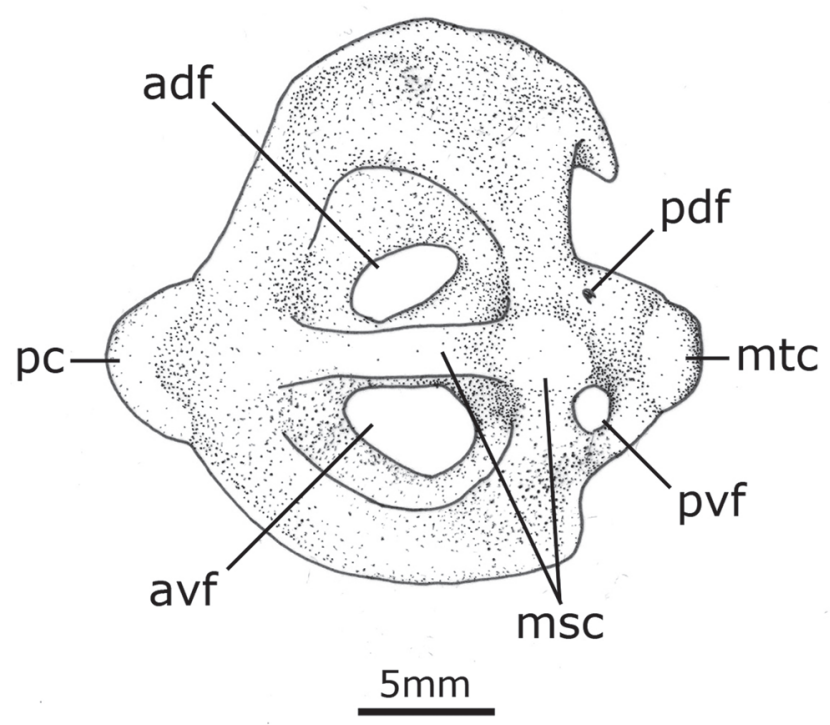

Fig. 8. Lateral view of pectoral girdle of Potamotrygon falkneri (MZUSP 106265, male, $231 \mathrm{~mm} \mathrm{DW);} \mathrm{adf,} \mathrm{anterodorsal} \mathrm{fenestra;}$ avf, anteroventral fenestra; msc, mesocondyle; mtc, metacondyle; pc, procondyle; pdf, posterodorsal fenestra; pvf, posteroventral fenestra. morphometric and merisitc comparison. The data concerning color pattern, external morphology (e.g., disposition of spines on dorsal tail), and morphometric and merisitc features obtained by Rosa mostly correspond to those obtained in the present study. Measurements and counts display similar values in both our studies, in particular the cloaca to sting distance $(52 \%$ vs. $52.1 \%$ of DW, respectively), mouth width $(8.6 \% v s .8 .8 \%$ of $\mathrm{DW}$ ), and mean values for number of total vertebrae (127 vs. 125.2) and pectoral radials (96.9 vs. 97.3).

Rosa (1985) offered the following characters as diagnostic of P. falkneri: dorsal surface of disc dark brown, with irregular, oval to reniform yellow spots, greater than eye diameter; five buccal papillae; small teeth, wider than long, with flattened crowns devoid of prominent cusps, except in adult males; spines disposed in irregular parallel rows. Two characters presented by Rosa (1985) as diagnostic-dorsal disc coloration and presence of cusps in mature males-have much greater intraspecific variation according to our results, which was based on considerably more material. Color pattern showed a greater range of spot shapes, not only varying from oval to reniform, but also in being circular,

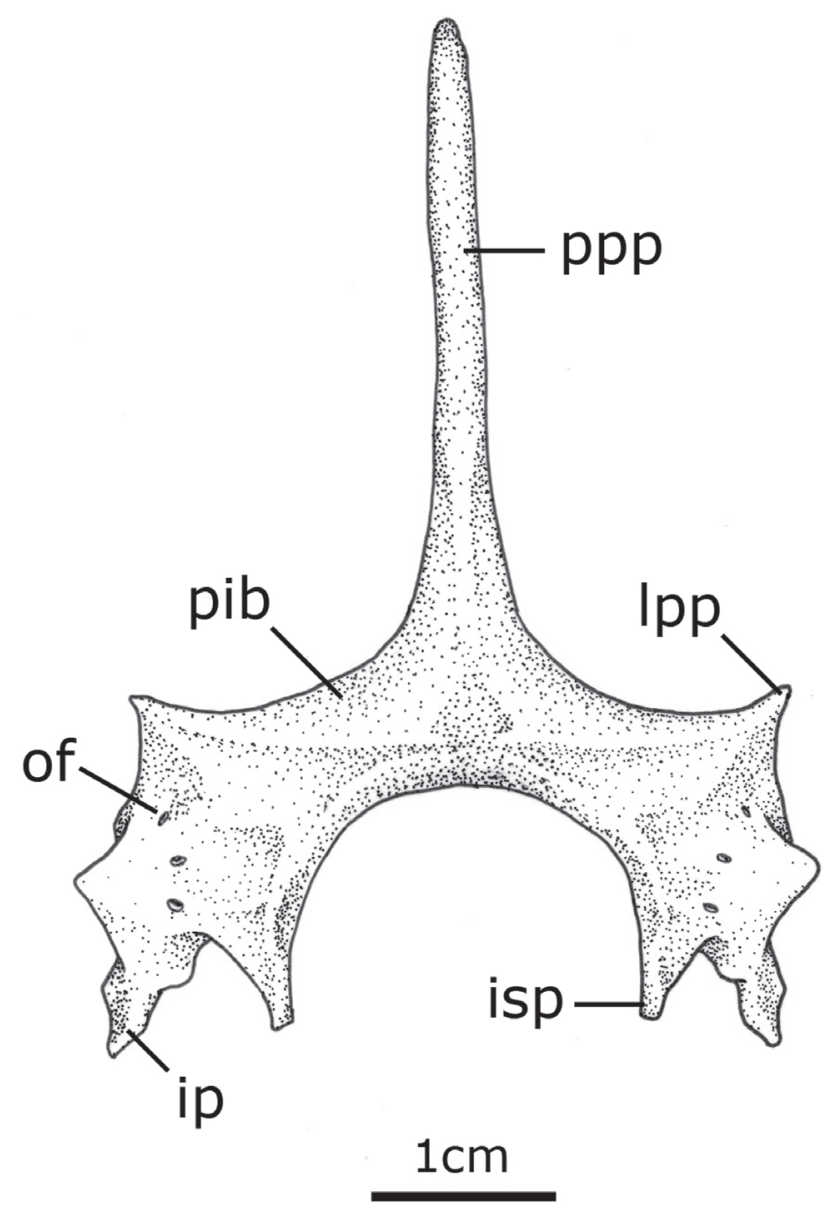

Fig. 9. Dorsal view of pelvic girdle of Potamotrygon falkneri (MZUSP 106265, male, $231 \mathrm{~mm} \mathrm{DW).} \mathrm{ip,} \mathrm{iliac} \mathrm{process;} \mathrm{isp,}$ ischial process; lpp, lateral prepelvic process; of, obturator foramen; ppp, prepelvic process; pib, puboischiadic bar. 


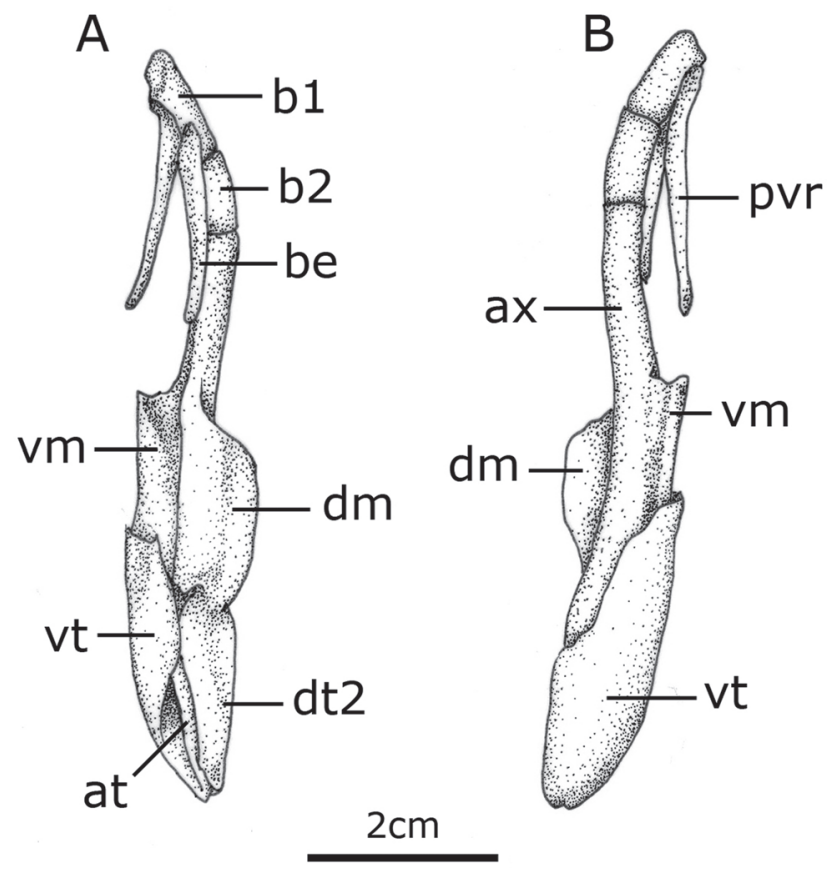

Fig. 10. Dorsal (A) and ventral (B) views of clasper of Potamotrygon falkneri (MZUSP 108683, male, $365 \mathrm{~mm}$ DW); at, accessory terminal; ax, axial cartilage; b1, first basal segment; b2, second basal segment; be, beta cartilage; dm, dorsal marginal; dt2, dorsal terminal 2; pvr, pelvic fin radial; $\mathrm{vm}$, ventral marginal; vt, ventral terminal.

vermicular and rosette-like; coloration of spots varied principally from beige to orange. Some mature males analyzed have teeth completely devoid of prominent cusps, similar to females. This variation in males was alluded to by Castex, who (Castex, 1964, 1965) credited males as bearing prominent cusps based on an "allotype" (MFA 279, a mature male devoid of type-status), but later contradicted this assertion (Castex, 1967b) based on a general study of the teeth of Potamotrygon species, stating that P. falkneri, together with $P$. menchacai and $P$. brachyura (Günther, 1880), formed a group in which males and females present equal-sized teeth, without prominent cusps. According to our results, presence of cusps in mature males should be considered variable in $P$. falkneri.

\section{Taxonomic status of Potamotrygon menchacai}

Some specimens examined present the diagnostic characters in dorsal disc coloration proposed in the original description of Potamotrygon menchacai. However, this minimal variation in dorsal color pattern easily fits within the variation we observed in $P$. falkneri; the remaining characters of $P$. menchacai correspond also with this species. Rosa (1985) and Carvalho et al. (2003) also interpreted the color pattern of $P$. menchacai as an example of intraspecific variation in P. falkneri. Castex (1967a), based on morphology and distribution of dermal denticles, united P. falkneri and $P$. menchacai in a species group. But according to Rosa (1985), the holotype of $P$. menchacai agrees with $P$. falkneri in all examined characters (dentition, tail spines, morphometrics, and meristics), except for the slight distinction in coloration. Considering that the holotype of P. menchacai is lost, no further information could be obtained from it and Rosa's statements could not be confirmed. In this manner, we found no evidence to contradict this synonymy, and $P$. menchacai is corroborated as a junior synonym of $P$. falkneri.

\section{Taxonomic status of Potamotrygon castexi}

Characters presented as distinct in the original description of Potamotrygon castexi are not really diagnostic. The original description of $P$. castexi is rather superficial, and was based on only three specimens, ranging in size from 560 to $810 \mathrm{~mm}$ TL (two males and one female), and collected from very proximal localities in Rosario. Many of the characteristics described as present and diagnostic in the holotype (e.g., rows of spines irregularly arranged on dorsal tail, lack of disc "defenses" on dorsal midline) correspond to features also mentioned in the original description of $P$. falkneri and observed in our material. The apparent exception is its distinct dorsal color pattern, which was given as displaying a brown background color with a relatively uniform reticulated pattern, consisting of a black colored mesh.

Our observations indicate, however, that $P$. castexi falls within the range of variation present in $P$. falkneri regarding morphological features, including the arrangement of dorsal tail spines, but especially in relation to coloration, the main diagnostic character believed to separate them (see also Rosa, 1985). In the present study, specimens presenting the "typical" dorsal coloration as described for P. falkneri (circular and elliptical beige to orange spots on a dark brown background; Fig. 1G, H) and P. castexi (small yellowish spots fused forming vermicular patterns or rosettes on dark brown background; Fig. 1I, J) were compared side-by-side along with putative conspecific specimens, revealing the great range in coloration and the existence of many intermediate color patterns (a mixture of randomly arranged circular, reniform, oval, vermicular, and/or rosette-like, beige and orange spots on a dark brown background). These specimens (Fig. 1G, H and Fig. 1I, J), when analyzed separately, and based on less material, had previously given the impression that they could be regarded as distinct (and hence $P$. castexi was recognized as valid by Carvalho et al., 2003). But this separation quickly became untenable once a significant amount of specimens was jointly analyzed. Specimens considered "typical" of these nominal species did not even represent the extremes of color variation examined (Fig. 1).

Other morphological features examined did not fare any better to separate $P$. castexi from $P$. falkneri. Other characters also presented too much variation and hence could not unequivocally separate them, such as the disposition of dorsal tail spine rows (varying from one to three irregular rows) and presence or absence of prominent cusps in mature males. The original description of $P$. castexi, having been based on 


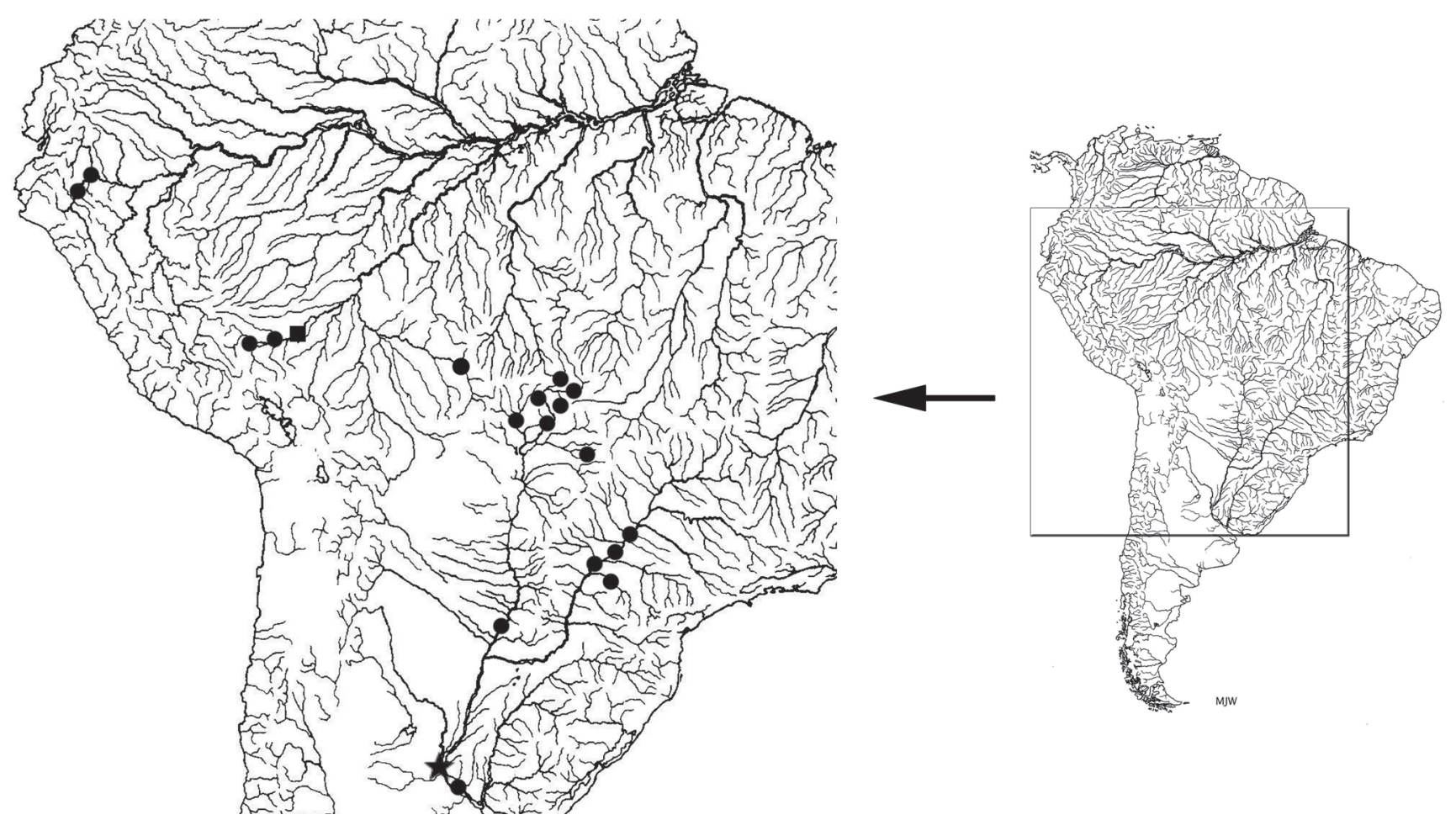

Fig. 11. Map showing geographic distribution of Potamotrygon falkneri and Potamotrygon sp. Circles indicate distribution of P. falkneri, square indicates locality of specimens of Potamotrygon sp., and star indicates type locality of P. falkneri.

few specimens, did not consider intraspecific variation and relied heavily on dorsal color as diagnostic. As in the original description of P.falkneri, characters that could help elucidate this taxonomic problem, such as dermal denticle morphology, were poorly treated. Also, in the original description of $P$. castexi the authors presented few measurements, such as total length, disc length, and disc width, and did not give any explanations about the methodology employed to obtain meristic data (e.g., tooth counts), precluding reliable comparisons with the data presented herein. In addition, all type material of $P$. castexi is presently missing and considered to have been lost (Carvalho et al., 2003). The great morphological variation encountered in this form, for which $P$. falkneri is the oldest available name, is responsible for the continued taxonomic confusion.

Rosa (1985) described the coloration of P. castexi differently from the original description of Castello \& Yagolkowski (1969), emphasizing the variation he observed in the spots: dorsal surface of disc and tail dark brown in coloration, with yellow spots forming vermiculations or rosettes and occasionally ocelli. Rosa (1985) also highlighted the fact that $P$. castexi and P. falkneri are sympatric in the lower Paraná-Paraguay basin and mentioned the existence of specimens from the rio Paraná with intermediate color patterns. He indicated that $P$. falkneri shares morphological similarities with $P$. castexi, such as dentition, shape and distribution of tail spines, and coloration, suggesting that they could form a species-group. He also indicated that mature males have prominent cusps, differing from the original description, wherein males are described as lacking prominent cusps. However, this observation in the original description is preliminary, being based only on two mature males.

It is important to highlight that the vast majority of specimens of $P$. castexi analyzed by Rosa (1985) came from the upper Amazon basin (from Bolivia and Peru), and that the same material was thoroughly examined by us (in addition to more material not available to Rosa at the time). We found no significant differences between most specimens from the Amazon and Paraná-Paraguay basins (the exception is Potamotrygon sp. from Peru, discussed below), after a detailed analysis of coloration, dermal derivatives, teeth, morphometrics, meristics, and external morphology (however, we did not examine the internal anatomy of the Amazonian material). Comparing the two tables summarizing morphometric data on material from these basins (Tables 1 and 2), it is clear that significant differences do not exist. Furthermore, morphometric and meristic data obtained by Rosa (1985) for $P$. castexi are very close to those obtained in the present study for P.falkneri (frequently overlapping), such as means of tail width ( $13.3 \%$ vs. $11 \%$ of DW, respectively), preoral length $(22.2 \%$ vs. $23.9 \%$ of DW), branchial basket length (15.7\% vs. $14.9 \%$ of DW), and total vertebrae (127 vs. 125.5). Thus, evidence presented by Rosa (1985) to separate $P$. castexi from $P$. falkneri further reinforces our interpretation that $P$. falkneri presents significant intraspecific variation and has a much greater geographical distribution. 
Taking into consideration that the original description of Potamotrygon castexi is rather superficial and based only on three specimens from almost adjacent localities, that the typelocality of $P$. castexi is itself from very close (about $146 \mathrm{~km}$ distant) to the type locality of $P$. falkneri, that Rosa (1985) and Carvalho et al. (2003) did not have available many specimens from the Paraná-Paraguay basin when they accepted $P$. castexi as valid (and separated this species from $P$. falkneri on the basis of dorsal color), and that $P$. falkneri presents elevated intraspecific variation in many morphological parameters, especially dorsal coloration, we can be confident that presently there is no way to morphologically differentiate these two nominal species. The specimen (MZUSP 14578, Fig.1I) previously identified as typical of P. castexi in Carvalho et al. (2003) and Rosa \& Carvalho (2007), for example, represents a specimen of $P$. falkneri with a slightly distinct color pattern in comparison to its type-specimens. Accordingly, the nominal species $P$. falkneri, $P$. castexi, and P. menchacai must be treated as a single, polychromatic species, a condition (polychromatism) that is very common among species of Potamotrygonidae. In particular, this variable dorsal coloration has lead to erroneous judgments on the identity of $P$. castexi, which had previously supported the notion that more than one "multi-spotted" species occured sympatrically in the Paraná-Paraguay basin, even though a secure means to separate both species was never unequivocally presented. According to the material
Table 4. Morphometric data of Potamotrygon sp. (río Madre de Díos, Peru). Data are expressed in millimeters and percentages of disc width (\% DW). SD = Standard deviation.

\begin{tabular}{lccccc}
\hline \multicolumn{1}{c}{ Measurements } & $\mathrm{n}$ & \multicolumn{2}{c}{ Range } & Mean & SD \\
\hline & 7 & $\mathrm{~mm}$ & \%DW & \%DW & \%DW \\
Total length & 7 & $480-755$ & $160.0-214.8$ & 195.2 & 18.2 \\
Disc length & 7 & $283-475$ & $102.6-131.2$ & 110.3 & 9.5 \\
Disc width & 7 & $265-362$ & - & - & - \\
Interorbital space & 7 & $32-51$ & $10.5-14.1$ & 11.8 & 1.1 \\
Interspiracular space & 7 & $51-75$ & $17.9-20.7$ & 19.0 & 0.9 \\
Eye length & 7 & $9-11$ & $2.8-3.8$ & 3.2 & 0.4 \\
Spiracle length & 7 & $19-30$ & $7.0-8.3$ & 7.4 & 0.6 \\
Sting length & 7 & - & - & - & - \\
Sting width & 7 & - & - & - & - \\
Preorbital length & 7 & $66-107$ & $23.9-29.6$ & 25.1 & 2.2 \\
Prenasal length & 7 & $41-74$ & $15.4-21.1$ & 18.1 & 2.5 \\
Preoral length & 7 & $54-95$ & $20.4-27.1$ & 23.3 & 2.9 \\
Internarial space & 7 & $23-32$ & $8.2-9.3$ & 9.0 & 0.5 \\
Mouth width & 7 & $23-40$ & $7.8-11.0$ & 9.5 & 0.9 \\
Space between 1 & 7 & $61-102$ & $22.7-28.2$ & 24.9 & 2.1 \\
Space between 5 branchial slits branchial slits & 7 & $44-71$ & $16.2-19.6$ & 17.8 & 1.4 \\
Branchial basket length & 7 & $44-66$ & $15.8-19.0$ & 17.1 & 1.2 \\
Pelvic fin length & 7 & $60-103$ & $20.2-28.5$ & 24.0 & 3.5 \\
Pelvic fin width & 6 & $144-235$ & $54.3-67.0$ & 62.2 & 4.2 \\
Clasper external edge & 6 & $32-50$ & $10.9-13.8$ & 12.3 & 1.1 \\
Clasper internal edge & 7 & $65-95$ & $22.3-27.3$ & 24.9 & 1.8 \\
Cloaca to tail tip & 7 & $252-400$ & $95.0-123.7$ & 109.0 & 10.8 \\
Tail width & 7 & $42-57$ & $14.0-16.2$ & 15.5 & 0.7 \\
Snout to cloaca & 7 & $237-369$ & $84.3-106.0$ & 92.4 & 9.2 \\
Pectoral axil to posterior & 7 & $35-66$ & $11.9-18.2$ & 13.5 & 2.0 \\
edge of pelvic fin & 7 & $145-217$ & $53.3-62.4$ & 57.8 & 3.3 \\
Cloaca to sting & & & & &
\end{tabular}

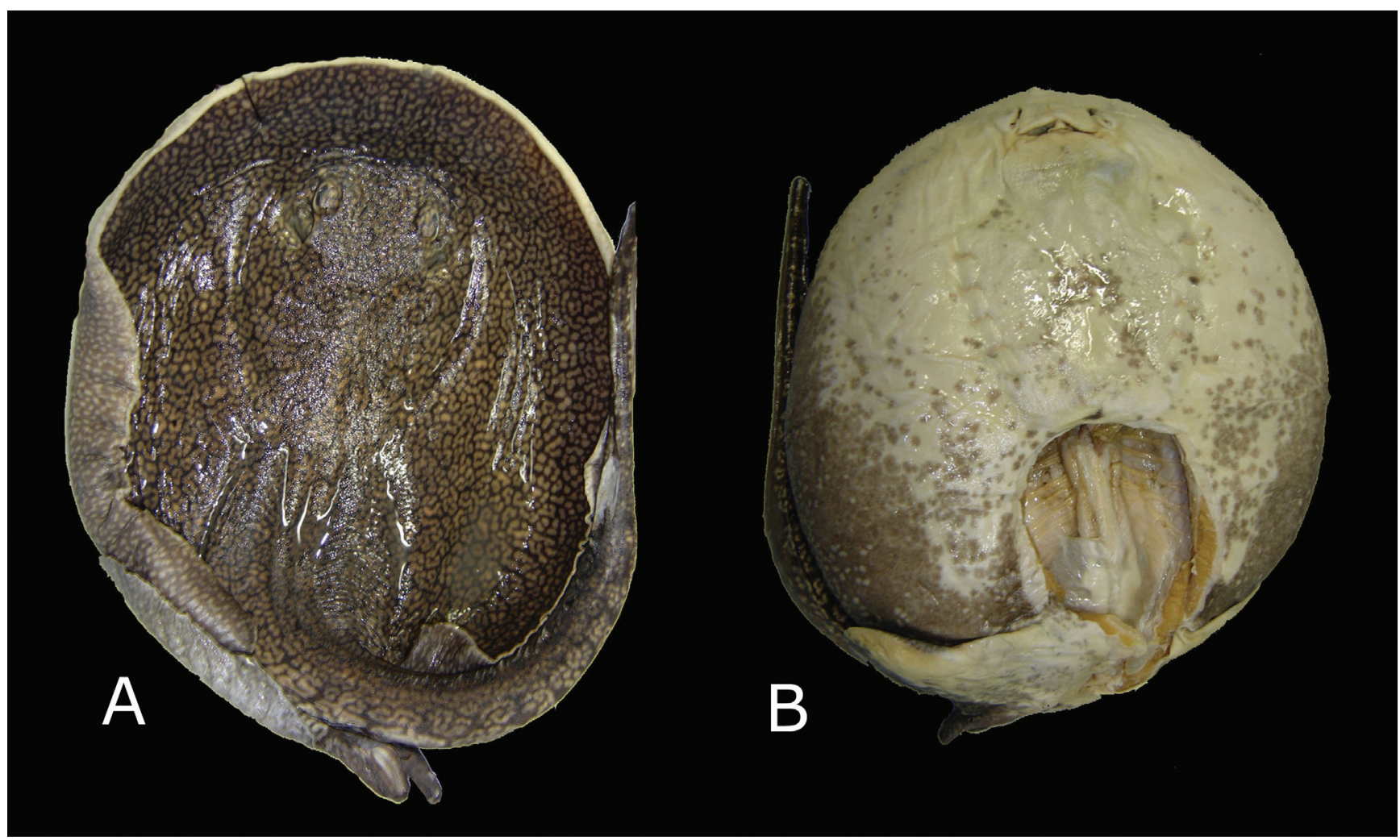

Fig. 12. Potamotrygon sp. MZUSP 107671 (río Madre de Díos, Peru), male, 351 mm DW, in dorsal (A) and ventral (B) views. 
analyzed, and considering $P$. castexi as a junior synonym of $P$. falkneri, the geographic distribution of $P$. falkneri is hereby extended from the Paraná-Paraguay and La Plata basins to the upper Amazon drainage (in Brazil, Bolivia and Peru).

\section{Comments on a putative new Potamotrygon species from Peru}

The second species herein identified is based on specimens from a single locality in the río Madre de Díos (upper rio Madeira basin, Peru). Although they present a color pattern (Figs. 12 and 13) similar to the one described for $P$. castexi $(=P$. falkneri), other characters proved diagnostic to separate these specimens from typical $P$. falkneri: uniformity in relation to spine row disposition over tail, being single and not nearly as irregular (vs. one to three irregular rows); dermal denticles practically devoid of crown dichotomies ( $v s$. high crown dichotomies); teeth devoid of prominent cusps in males, with males and females presenting equal-sized, morphologically similar teeth ( $v s$. some males bearing prominent cusps); tail homogeneously grey on its central, ventral portion, with irregular white spots scattered laterally ( $v s$. disorganized reticulated pattern on tail, formed by irregular vermicular white spots); coloration on dorsal disc exclusively composed of slender vermiculations ( $v s$. spots on background presenting mainly circular, reniform, and oval shapes, with diameter equal to or smaller than eye diameter); and number of total pectoral radials slightly lower (but continuous: 90-93 vs. 94-100, respectively). Vertebral numbers, however, overlap significantly (123-132 vs. 120-136, respectively). Also, the Peruvian form has considerably longer tails $(\mathrm{n}=7$, mean $=109 \%$ of DW) compared to $P$. falkneri $(\mathrm{n}=$ 65 , mean $=87.9 \% \mathrm{DW})$, which is due to its characteristically
Table 5. Meristic data of Potamotrygon sp. (río Madre de Díos, Peru). $\mathrm{SD}=$ Standard deviation.

\begin{tabular}{lcccc}
\hline \multicolumn{1}{c}{ Counts } & $\mathrm{n}$ & Range & Mean & SD \\
\hline Precaudal vertebrae & 5 & $27-32$ & 29.4 & 1.8 \\
Caudal vertebrae & 5 & $92-103$ & 98.2 & 4.3 \\
Total vertebrae & 5 & $123-132$ & 127.8 & 4.1 \\
Diplospondylous vertebrae & 4 & $92-100$ & 96.0 & 3.7 \\
Upper tooth rows & 4 & $36-44$ & 39.5 & 3.3 \\
Lower tooth rows & 4 & $33-45$ & 37.5 & 5.3 \\
Propterygial radials & 5 & $42-44$ & 42.4 & 0.9 \\
Mesopterygial radials & 5 & $14-15$ & 13.8 & 0.4 \\
Metapterygial radials & 5 & $34-36$ & 35.0 & 1.2 \\
Total pectoral radials & 5 & $90-93$ & 91.2 & 1.3 \\
Pelvic radials (male) & 5 & $21-22$ & 21.2 & 0.4 \\
\hline
\end{tabular}

elongate tail posterior to sting insertion. This greater extension does not have direct influence on the number of total vertebrae (Tables 4 and 5), but is associated to the presence of a longer cartilaginous rod which supports the distal part of tail posterior to vertebral centra (individual centra do not occur posterior to caudal stings). Snout to cloaca $(\mathrm{n}=7$, mean $=92.4 \% v s . \mathrm{n}=65$, mean $=87.3 \% \mathrm{DW})$, pelvic fin length $(\mathrm{n}=7$, mean $=62.2 \%$ vs. $\mathrm{n}=65$, mean $=57 \%$ DW) and branchial basket length $(\mathrm{n}=7$, mean $=17.1 \% v s . \mathrm{n}$ $=65$, mean $=15.7 \% \mathrm{DW}$ ) present slightly higher values too. Considering that this form requires further study and additional material to corroborate its distinctiveness from $P$. falkneri, and that it resembles this species in many aspects (e.g., many proportional measurements, ventral disc coloration, tooth shape, number of tooth rows, and number of total vertebrae), it is best to presently refer to it as Potamotrygon sp., as no available nominal species exists for

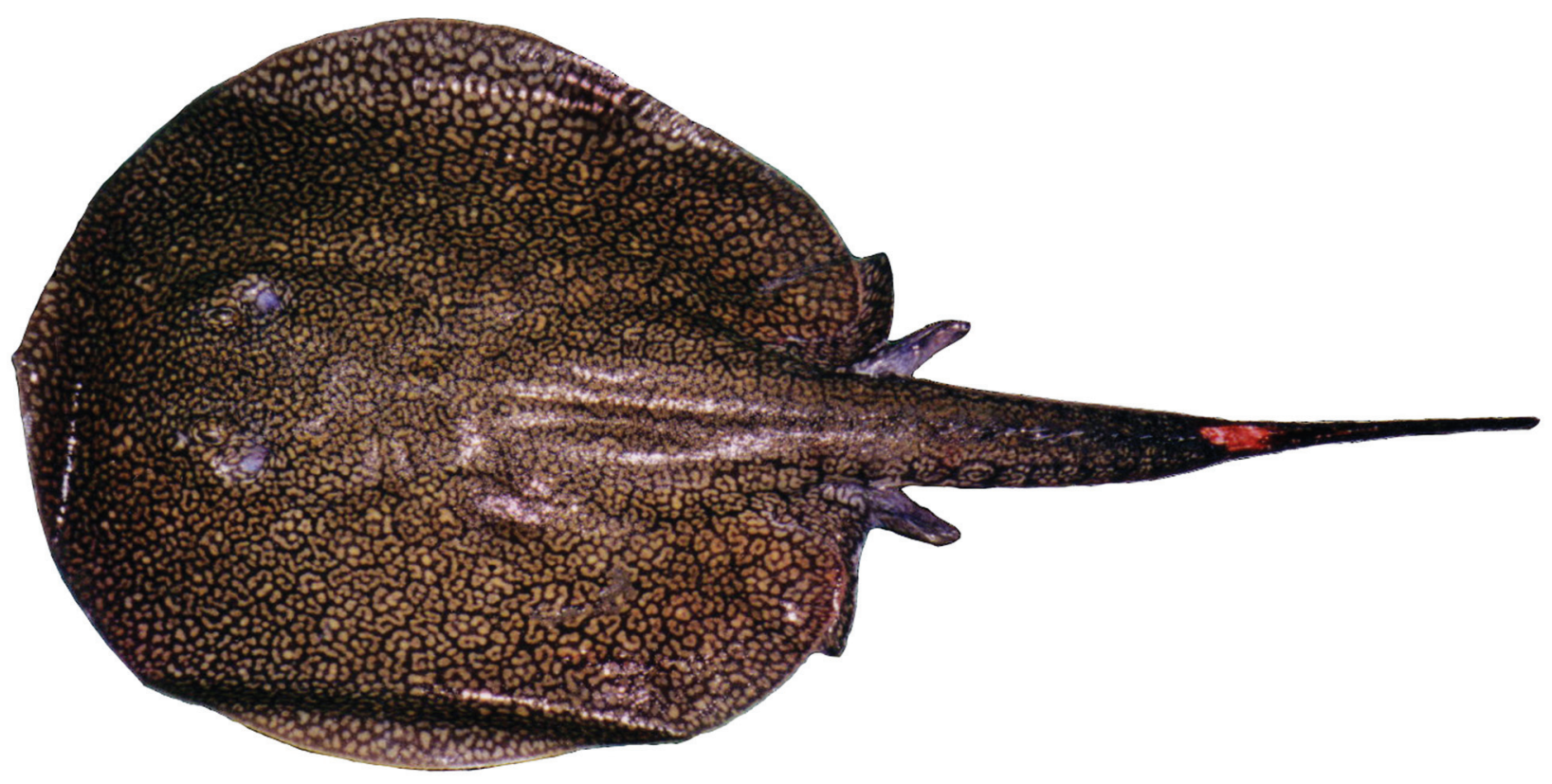

Fig. 13. Dorsal view of Potamotrygon sp. MZUSP 107671, male, $351 \mathrm{~mm}$ DW (specimen photographed in the field). 
this form. Some of the characters mentioned above as distinctive may prove to be variable when a greater number of specimens are examined (given our experience with species of Potamotrygon in general), and therefore its separation must be considered preliminary.

\section{Acknowledgements}

Members of the Laboratório de Ictiologia de Ribeirão Preto are acknowledged for support, especially Adriana Takako, Aléssio Datovo, Murilo Carvalho, and Vítor L. Masson. Thiago Silva Loboda (Instituto de Biociências, USP) is thanked for his considerable help during this study. We are grateful to Profs. Flávio A. Bockmann (Departamento de Biologia, Faculdade de Filosofia, Ciências e Letras de Ribeirão Preto, USP) and Ulisses L. Gomes (Universidade do Estado do Rio de Janeiro) for their support and pertinent suggestions. Profs. José Lima de Figueiredo, Naércio A. Menezes, and Osvaldo T. Oyakawa (MZUSP) are thanked for their help and support during numerous visits to the Museu de Zoologia da Universidade de São Paulo. Andrés Pautasso (MFA), Gustavo E. Chiaramonte and Francisco Firpo (MACN), and Melanie Stiassny, Scott Schaefer, Bob Schelly, Rad Arindell and Barbara Brown (AMNH), are thanked for their help and hospitality during visits to their institutions. We thank Mark Sabaj (ANSP), Mary Ann Rogers (FMNH), Gerald Smith and Doug Nelson (UMMZ), and Chris Thacker and Jeff Seigel (LACM) for sending specimens to the AMNH for examination. Gilmar de Oliveira (Radiologia, Hospital Central, Universidade de São Paulo, Ribeirão Preto) is sincerely thanked for taking radiographs of Potamotrygon specimens. We are grateful to Carla S. Pavanelli (Núcleo de Pesquisas em Limnologia, Ictiologia e Aquicultura, Maringá) and Fernando P. L. Marques (Departamento de Zoologia, Instituto de Biociências, Universidade de São Paulo, São Paulo; supported by research grants Fapesp 03/01816-2, 05/01299-3, 08/09436-8) for making available material for this study. Weferson J. da Graça (NUPELIA) is thanked for his help with specimen localities, and Mauro C. Júnior, Marcus V. Domingues, Natalia da Mata Luchetti, and Verônica M. Bueno (Laboratório de Helmintologia Evolutiva, IB, USP) are thanked for their help during field and laboratory work. This project was funded by the Fundação de Amparo à Pesquisa do Estado de São Paulo (FAPESP) through grants to the first (05/52985-4) and second (02/06459-0; 10/51193-5) authors. MRC also acknowledges financial support from the Conselho Nacional de Desenvolvimento Científico e Tecnológico (CNPq 303061/ 2008-1).

\section{Literature Cited}

Achenbach, G. M. 1967. Nota sobre una nueva especie de raya fluvial (Batoidei, Potamotrygonidae) pescada en el rio colastine (Paraná médio, Departamento La Capital, Provincia de Santa Fé, República Argentina). Comunicaciones del Museo Provincial de Ciencias Naturales Florentino Ameghino, 1: 1-7.
Achenbach, G. M. 1971. Nota acerca de un espécimen del género Potamotrygon (Chondricthyes, Potamotrygonidae). Comunicaciones del Museo Provincial de Ciencias Naturales, 5: 1-10.

Achenbach, G. M. \& S. V. M. Achenbach. 1976. Notas acerca de la raya fluvial (Batoidei, Potamotrygonidae), que frecuentam el sistema hidrográfico del Río Paraná Médio en el Departamento La Capital. Comunicaciones del Museo Provincial de Ciencias Naturales, 8: 3-34.

Bigelow H. B. \& W. C. Schroeder. 1953. The Fishes of the Western North Atlantic, Part II. Sawfishes, Skates, Rays and Chimaeroids. Memoirs of the Sears Foundation for Marine Research, 588p.

Bor, P. H. F. 2002. Nederlandse naamlijst van de recente haaien en roggen (Chondrichthyes: Elasmobranchii) van de wereld. Version 05/2002, 34p. Available at : http://www.rajidae.tmfweb.nl (10/ 2006).

Britski, H. A., K. Z. S. Silimon \& B. S. Lopes. 1999. Peixes do Pantanal: manual de identificação. Brasília, Embrapa, 184p.

Brooks, D. R., T. B. Thorson \& M. A. Mayes. 1981. Fresh-water stingrays (Potamotrygonidae) and their helminth parasites: testing hypothesis of evolution and coevolution. Pp. 147-175. In: Funk, V. A. \& D. R. Brooks (Eds.). Advances in Cladistics, Proceedings of the First Meeting of the Willi Hennig Society. New York Botanical Garden, New York.

Carvalho, M. R. de. 2001. Freshwater stingrays from South America (review). Copeia, 2001(4): 1167-1169.

Carvalho, M. R. de \& N. R. Lovejoy. 2011. Morphology and phylogenetic relationships of a remarkable new genus and two new species of Neotropical freshwater stingrays from the Amazon basin (Chondrichthyes: Potamotrygonidae). Zootaxa, 2776: 13-48.

Carvalho, M. R. de, N. R. Lovejoy \& R. S. Rosa. 2003. Family Potamotrygonidae. Pp. 22-29. In: Reis, R. E, C. J. Feraris Jr. \& S. O. Kullander (Eds.). Checklist of the Freshwater Fishes of South and Central America. Porto Alegre, Edipucrs, 729p.

Carvalho, M. R. de, J. G. Maisey \& L. Grande 2004. Freshwater stingrays of the Green River Formation of Wyoming (Early Eocene), with the description of a new genus and species and an analysis of its phylogenetic relationships (Chondrichthyes: Myliobatiformes). Bulletin of the American Museum of Natural History, 284: 1-136.

Castello, H. P. \& D. R. Yagolkowski. 1969. Potamotrygon castexi (Condrichthyes, Potamotrygonidae), a new species of freshwater sting-ray for the Paraná River. Acta Scientifica, Universidad del Salvador, 6: 1-21.

Castex, M. N. 1963a. La raya fluvial. Notas histórico-geográficas. Librería y Editorial Castellví, Santa Fe, 119p.

Castex, M. N. 1963b. El género Potamotrygon en el Paraná medio. Anales del Museo Provincial de Ciencias Naturales Florentino Ameghino. Santa Fe, Zoologia, 2(1): 1-86.

Castex, M. N. 1964. Estado actual de los estudios sobre la raya fluvial Neotropical. Cincuentenario del Museo Provincial de Ciencias Naturales "Florentino Ameghino,": 9-50.

Castex, M. N. 1965. Notas acerca del "Potamotrygon hystrix" y del "Potamotrygon falkneri" en la cuenca del Plata. Comunicaciones del Museo Argentino de Ciencias Naturales Bernardino Rivadavia. Hidrobiología, 1(5): 38-46.

Castex, M. N. 1967a. Observaciones en torno a las formaciones estelares que recubren el dorso de algunas especies de rayas de agua dulce. Physis, 26(73): 485-491. 
Castex, M. N. 1967b. Notas sobre los dientes de las especies del género Potamotrygon Garman, 1877 (Chondrichthyes: Potamotrygonidae). Physis, 26(76): 493-496.

Castex, M. N. \& I. Maciel. 1963. Caracteristicas del Potamotrygon falkneri sp. n., In: El género Potamotrygon en el Paraná medio. Anales del Museo Provincial de Ciencias Naturales Florentino Ameghino, Zoologia, 2(1): 56-61

Chu, Y. T. \& C. M. Wen. 1979. A study of the lateral-line canals system and that of Lorenzini ampullae and tubules of Elasmobranchiate fishes of China. Monograph of Fishes of China. 2. Shangai, People's Republic of China: Shangai Science and Technology Press.

Compagno, L. J. V. 1973. Interrelationships of living elasmobranchs. In: Greenwood, P. H., C. Patterson \& R. S. Miles (Eds.). Interrelationships of fishes. Zoological Journal of the Linnean Society. London, Academic Press, 53: 15-61.

Compagno, L. J. V. 1988. Sharks of the order Carcharhiniformes. Princeton, Princeton University Press, 604p.

Compagno, L. J. V. \& T. Roberts. 1982. Freshwater stingrays (Dasyatidae) of southeast Asia and New Guinea, with descriptions of a new species of Himantura and reports of unidentified species. Environmental Biology of Fishes, 7(4): 321-339.

Compagno, L. J. V. \& S. F. D. Cook. 1995. The exploitation and conservation of freshwater elasmobranchs: status of taxa and prospects for the future. Pp. 62-90. In: Oetinger, M. I. \& G. D. Zorzi (Eds.). The Biology of Freshwater Elasmobranchs. Journal of Aquariculture \& Aquatic Sciences, volume VII.

Compagno, L. J. V. 1999. Checklist of living elasmobranches. Pp. 471-498. In: Hamlett, W. C. (Ed.). Sharks, skates and rays, the biology of elasmobranch fishes. Baltimore, The John Hopkins University Press, 515p.

Compagno, L. J. V. 2005. Checklist of living chondrichthyes. Pp. 503-548. In: Hamlett, W. C. (Ed.). Reproductive biology and phylogeny of chondrichthyes: sharks, batoids and chimaeras. Science Publishers, Inc. Enfield (NH), Unite States of America, 562p.

Deynat, P. \& B. Séret. 1996. Le revêntement cutané des raies (Chondrichthyes, Elasmobranchii, Batoidea) I - Morphologie et arrangement des denticules cutanés. Annales des Sciences Naturelles, Zoologie, 17(2): 65-83.

Deynat, P. 2006. Potamotrygon marinae n. sp., une nouvelle espèce de raies d'eau douce de Guyane (Myliobatiformes, Potamotrygonidae). Comptes Rendu Biologies, 329(7): 483-493.

Dingerkus, G. \& L. D. Uhler. 1977. Enzyme clearing of alcian blue stained whole smalle vertebrates for demonstration of cartilage. Stain Technology, 52(4): 229-232.

Ewart J. C. \& H. C. Mitchell. 1892. On the lateral sense organs of elasmobranchs. II. The sensory canals of the common skate (Raja batis). Transactions of the Royal Society of Edinburgh, 37: $87-105$.

Garman, S. 1888. On the lateral canal system of the Selachia and Holocephala. Bulletin of the Museum of Comparative Zoology, 17: 57-119.

Garrone Neto, D, V. Haddad Jr., M. J. A. Vilela \& V. S. Uieda. 2007. Registro de ocorrência de duas espécies de potamotrigonídeos na região do Alto Rio Paraná e algumas considerações sobre sua biologia. Biota Neotropica, 7(1): 205-208.

Gómez, S. E. \& J. C. Chebez. 1996. Peces de la provincia de Misiones. Pp. 39-70. In: Chebez, J. C. (Ed.). Fauna Misionera, Catálogo sistemático y zoogeográfico de los vertebrados de La Provincia de Misiones (Argentina). L. O. L. A., Buenos Aires, $318 \mathrm{p}$.
Graça, W. J. \& C. S. Pavanelli. 2007. Peixes da planície de inundação do alto rio Paraná e áreas adjacentes. Maringá, Eduem, $241 \mathrm{p}$.

ICZN 1999. International Code of Zoological Nomenclature. Fourth Edition, London: The International Trust for Zoological Nomenclature.

Ishihara, H. \& T. Taniuchi. 1995. A strange potamotrygonid ray (Chondrichthyes: Potamotrygonidae) from the Orinoco river system. Pp. 91-97. In: Oetinger, M. I. \& G. D. Zorzi (Eds.). The Biology of Freshwater Elasmobranchs, a Symposium to Honor Thomas B. Thorson. Journal of Aquariculture \& Aquatic Sciences, volume VII.

Lonardoni, A. P., E. Goulart, E. F. Oliveira \& M. C. F. Abelha. 2006. Hábitos alimentares e sobreposição trófica das raias Potamotrygon falkneri e Potamotrygon motoro (Chondrichthyes, Potamotrygonidae) na planície alagável do alto rio Paraná, Brasil. Acta Scientiarum. Biological Sciences, Maringá, 28(3): 195-202.

López, H. L., A. M. Miquelarena, \& R. C. Menni. 2003. Lista comentada de los peces continentales de la Argentina. ProBiota, Serie Técnica y Didáctica $\mathrm{n}^{\circ} 5,87 \mathrm{p}$.

López, H. L., A. M. Miquelarena, \& J. Ponte Gómez. 2005. Biodiversidad y distribución de la ictiofauna Mesopotámica. Miscellánea, 14: 311-354.

Lovejoy, N. R. 1996. Systematics of myliobatoid elasmobranchs: with enphasis on the phylogeny and historical biogeography of neotropical freshwater stingrays (Potamotrygonidae: Rajiformes). Zoological Journal of the Linnean Society, 117: 207-257

Lundberg, J. G., L. G. Marshall, J. Guerrero, B. Horton, M. C. S. L. Malabarba \& F. Wesselingh. 1998. The stage for Neotropical fish diversification: a history of tropical South American rivers. Pp. 13-48. In: Malabarba, L. R., R. E. Reis, R. P. Vari, Z. M. S. Lucena \& C. A. S. Lucena (Eds.). Phylogeny and Classification of Neotropical Fishes. Porto Alegre, Edipucrs, 603p.

Marques, F. P. L. 2000. Evolution of Neotropical freshwater stingrays and their parasites: taking into account time and space. Unpublished PhD thesis. Toronto, University of Toronto, $325 \mathrm{p}$.

Marques, F. P. L., D. R. Brooks \& M. L. G. Araújo. 2003. Systematics and Phylogeny of Potamotrygonocestus (Plathyelminthes: Tetraphyllidea: Onchobothriidae) with descriptions of three new species from freshwater potamotrygonids (Myliobatoidei: Potamotrygonidae). Zoologica Scripta, 32: 367-396.

McEachran, J. D., K. Dunn \& T. Miyake. 1996. Interrelationships of batoid fishes. Pp. 63-84. In: M. L. J. Stiassny, G. D. Johnson \& L. Parenti (Eds.). Interrelationships of fishes. Academic Press, United States of America, 496p.

Menni, R. C. 2004. Peces y ambientes en la Argentina continental. Monografías del Museo Argentino de Ciencias Naturales. Estudio Sigma, Buenos Aires, 5: 1-316.

Nishida, K. 1990. Phylogeny of the suborder Myliobatidoidei. Memoirs of the Faculty of Fisheries Hokkaido University, 37(1/ 2): 1-108.

Ortega, H. \& R. P. Vari. 1986. Annotated checklist of the freshwater fishes of Peru. Smithsonian Contributions to Zoology, (437): $1-25$.

Rosa, R. S. 1985. A systematic revision of the South American freshwater stingrays (Chondricthyes: Potamotrygonidae). Unpublished PhD Thesis, College of William and Mary, Williamsburg, 523p. 
Rosa, R. S., H. Castello \& T. B. Thorson. 1987. Plesiotrygon iwamae, a new genus and species of neotropical freshwater stingray. Copeia, 1987(2): 447-458.

Rosa, R. S. \& M. R. de Carvalho. 2007. Família Potamotrygonidae. Pp. 1-9. Em: Buckup, P. A., N. A. Menezes \& M. S. Ghazzi (Eds.). Catálogo de peixes de água doce do Brasil. Museu Nacional, Rio de Janeiro, 195p.

Rosa, R. S., M. R. de Carvalho \& C. A. Wanderley. 2008. Potamotrygon boesemani (Chondrichthyes: Myliobatiformes: Potamotrygonidae), a new species of Neotropical freshwater stingray from Surinam. Neotropical Ichthyology, 6 (1): 1-8.

Rosa R. S. \& N. A. Menezes 1996. Relação preliminar das espécies de peixes (Pisces, Elasmobranchii, Actinopterygii) ameaçadas no Brasil. Revista Brasileira de Zoologia, 13 (3): 647-667.

Silva, T. B. \& V. S. Uieda. 2007. Preliminary data on the feeding habits of freshwater stingrays Potamotrygon falkneri and Potamotrygon motoro (Potamotrygonidae) from the Upper Paraná River basin, Brazil. Biota Neotropica, 7 (1): 221-226.

Taniuchi, T. \& H. Ishihara. 1990. Anatomical Comparison of Claspers of Freswater Stingrays (Dasyatidae and Potamotrygonidae). Japanese Journal of Ichthyology, 37 (1): 10-16.

Velte, F. 2005. Neues zur Zucht und Fortpflanzungsbiologie südamerikanischer Süßwasserstechrochen. Deutsch Elasmobranchier Gesellschaft. Elasmoskop 2005, Pp 53-54. Available at: http://www.elasmo.de/dok/elasmoskop/1_2005/ Zucht_Suesswasserstechrochen.pdf (10/2006).

Accepted December 28, 2010

Published March 31, 2011 